\title{
A educación nos Países Baixos nos anos 30 do século XIX: informes e textos de Ramón de la Sagra
}

Antón COSTA RICO

Universidade de Santiago

\begin{abstract}
Para os compañeiros e compañeiras do Grupo Sarmiento, e tamén para os demais historiadores da educación de Galicia. Chufarán con ledicia da galeguidade de La Sagra.
\end{abstract}

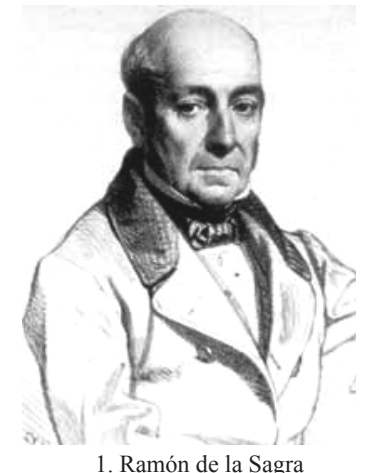

1. Ramón de la Sagra

\section{Cosmopolitismo e cambios sociais no escenario europeo}

Transcorridas as primeiras décadas do século XIX asistíase en parte de Europa e na Gran Bretaña a un deses momentos aos que os historiadores se refiren como de "aceleración da historia", que se irradiará ao conxunto europeo, e no que se examinará o lugar concedido á educación, entre outras institucións sociais. Observábanse os efectos das nacentes revolucións económicas e industriais, coa punta de lanza inglesa, pero tamén os da revolución política, con Francia

na vangarda. París convertíase, desde todo punto de vista, no maior laboratorio social ${ }^{1}$. A súa poboación crecía vertixinosamente até chegar en pouco tempo ao millón e medio de habitantes e ía vivir un período dunha grande intensidade social; un tempo de debates, de diatribas, de demandas, e de creatividade ideolóxica, que tivo resoancias noutras terras europeas orientais e occidentais.

Baixo o peso destas transformacións, que incluían o asentamento do modelo liberal e burgués, facíanse de cada vez máis visibles novas problemáticas sociais e desaxustes entre os distintos sectores e xerminais clases sociais. Emerxía a nova "cuestión social", que a literatura e outros textos recollen a modo de denuncia e novas voces, tamén femininas, se deixaban oír, no parlamento ou na rúa, nas academias ou na prensa, nos clubes de opinión (147 había en París en 1848) e na literatura; son os intelectuais, que contribúen á construción dun novo espazo

\footnotetext{
${ }^{1}$ Así o veu subliñar recentemente Peter Burke, Historia del conocimiento científico. Vol. II: De la Enciclopedia a la Wikipedia (Barcelona: Paidós, 2012): 236 e ss.
} 

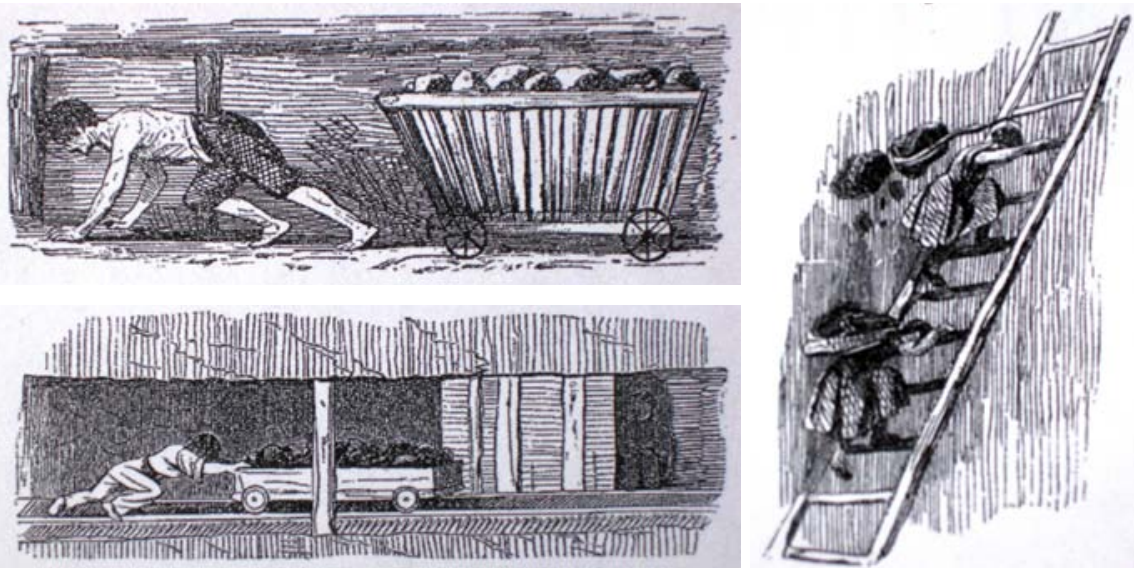

2, 3,- Imaxes sobre o traballo infantil nas minas inglesas a comezos do século XIX

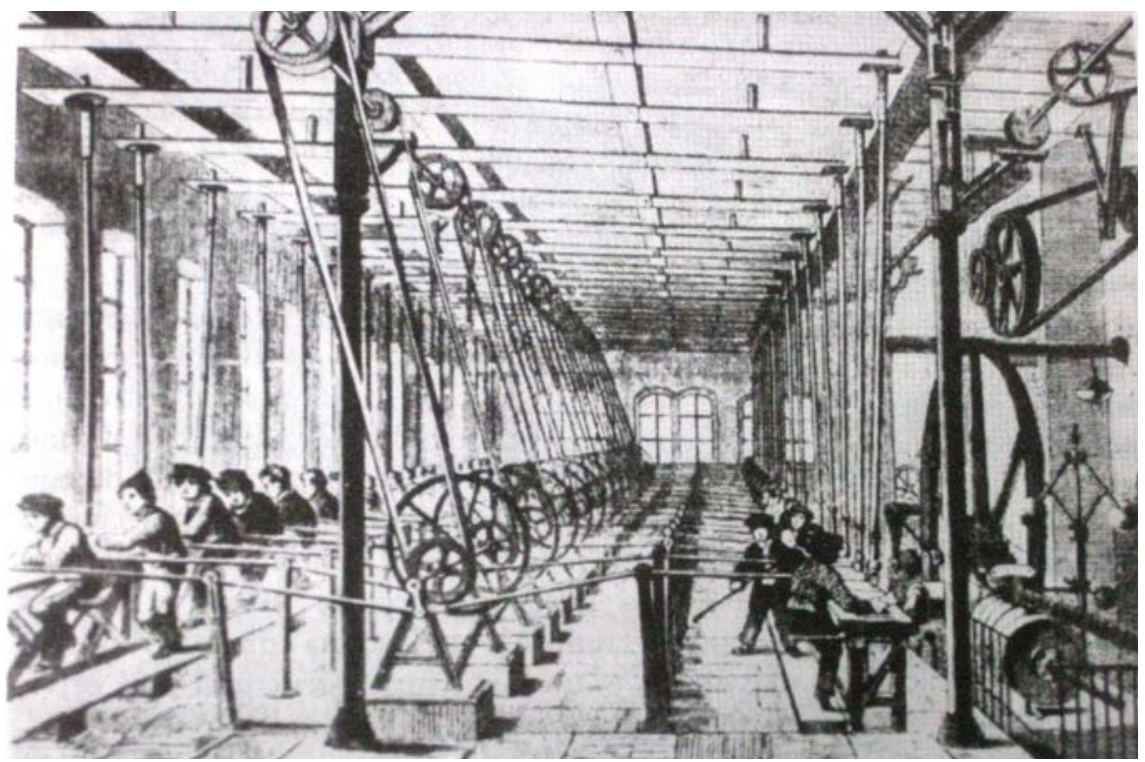

4.- Traballo infantil na industria téxtil en Inglaterra

público²: Saint-Simon (1760-1825) e os sansimonianos, os liberais doctrinarios, como François Guizot, Thiers ou Victor Cousin, os utópicos e demócratas humanitarios, como Pierre Lerroux, fundador en 1830 da "Societé des Amis du Peuple”, os neocatólicos como De Lamennais, Alban Bergemont o Sainte-Beuve,

${ }^{2}$ Christrphe Charle, Los intelectuales en el siglo XIX. Precursores del pensamiento moderno (Madrid: Siglo XXI, 2000) passim. 
os socialistas como Louis Blanc, Auguste Blanqui ou Etienne Cabet, os socialistas utópicos como Proudhon, coa súa posición favorable ao establecemento dunha sociedade de pequenos produtores, Fourier, co seu proxecto de falangsterios, ou Victor Considérant, crítico da economía capitalista, director de La Democratie Pacifique, mais tamén temeroso da revolución e favorable aos "cambios desde arriba".

Xunto de todos os anteriores, nunha cidade chea de liberais, demócratas e socialistas, había un alto número de exiliados políticos de distintas procedencias: polacos, belgas, italianos, españois ou alemáns, coas súas varias sociedades e entre elas "A liga dos xustos", que iría desembocar en 1837 en Bruxelas na "Liga de los comunistas" impulsada por Karl Marx. Sentíanse as voces partidarias da xustiza social, do pacifismo, dos dereitos dos nenos, da liberdade de prensa e imprenta, e de tantas outras reivindicaciones. E parecíalle a algúns necesario asentar unha nova orientación moral en consonancia coas novas necesidades de reforma que reclamaban tantas voces disidentes, tanto da vella e tradicional orde aristocrática, como contrarias aos efectos negativos do novo modelo económico capitalista. Un empirismo sen límite e unha moralidade de laissez-faire eran inaceptables para un sector amplo e consciente da sociedade ${ }^{3}$.

Un dos personaxes que aquí intervén será Claude Henry de Rouvray, conde de Saint-Simón (1760-1825) quen, partindo do positivismo científico como método e dun renovado cristianismo ${ }^{4}$, elabora a filosofía do organicismo evolucionista como guía para unha política reformista e "positiva", desde a que organizar a sociedade. Formulaba Saint-Simon unha orientación tecnocrática, desde a que concedía grande relevancia á ciencia e á técnica, comasí a unha minoría de "políticos responsables" e ao desenvolvemento da educación, con singular atención á educación moral ${ }^{5}$ e á instrución das incipientes clases medias, a fin de lograr una "sociedade harmónica", en correspondencia coas aspiracións da burguesía reformista.

Neste clima tiña lugar un moi rico intercambio de ideas relacionadas coa teoría social, cos modelos políticos, coa economía, co desenvolvemento científicotécnico e coa vida cotidiana. Os clubes de opinión, a incesante creación de medios de información impresa, a convocatoria de congresos e de exposicións de carácter internacional $^{6}$, entre outras vías, facilitaban a extensión das novidades ou das

\footnotetext{
${ }^{3}$ James Bowen, Historia de la educación occidental. T. III: El Occidente Moderno (Barcelona, Herder, 1985): 272 .

${ }^{4}$ Antonio Guerrero Serón, Enseñanza y Sociedad. El conocimiento sociológico de la educación (Madrid, Siglo XXI, 2003): 24.

${ }^{5}$ Maurice Dommanget, Os grandes socialistas e a educaçâo (Lisboa: Publicaçôes Europa-América, 1974).

${ }^{6}$ Estas exposicións, que permitían informar, ver e apreciar as descobertas científicas e tecnolóxicas, daban tamén acollida a algúns outros rexistros relativos á arte e ao coñecemento das culturas. Concibidas como vínculos de unión e intercambio entre os diferentes países, eran, así mesmo, un dos motores de avance das revolucións liberais do XIX.
} 


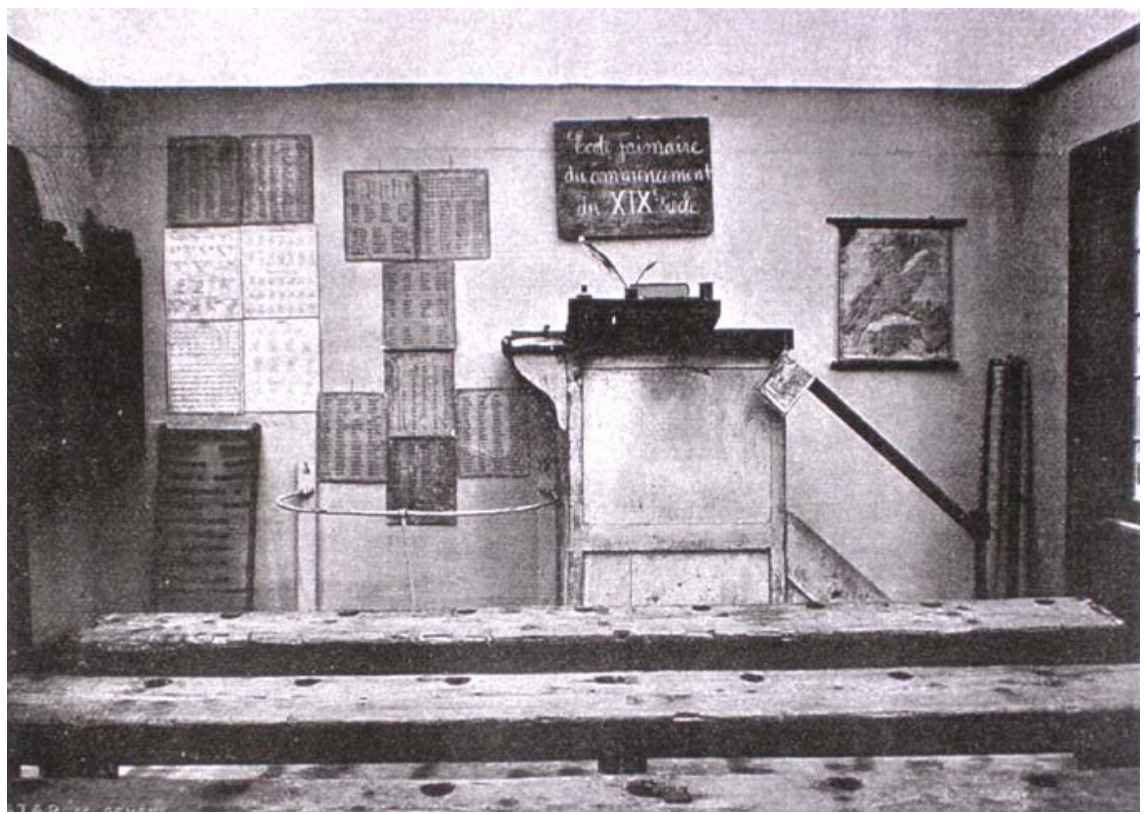

5.- Aula de escola primaria a inicios do século XIX

controversias, contribuíndo á fragua de sectores intelectuais transnacionais ${ }^{7}$, que se posicionaban como novas redes de 'expertos'. De todo isto facíase cargo, Ramón de la Sagra, quen, sendo unha personalidade destacada e recoñecida en varios campos científico-técnicos e sociais, e tendo permanencia no París de aqueles días, podía participar en aquel escenario.

\section{Progreso, Reforma Social y Educación}

Para os membros da "escola sansimoniana" a educación (máis importante cá instrución) habería de desempeñar un notable papel como mecanismo que garantizase a moral común e como instrumento clasificador e seleccionador, con capacidade para situar a cada traballador no marco das 'esixencias sociais', combinando, pois, unha educación moral ou xeral e unha educación especial ou profesional, coñecida como instrución ${ }^{8}$, en beneficio dunha determinada imaxe do progreso social.

\footnotetext{
${ }^{7}$ A este respecto: Chris Leonards\& Nico Randeraad: "Transnational experts in Social Reform, 18401880", en International Review of Social History, num. 55, (2010): 215-239; Mónica Burguera: "Ramón de la Sagra: Social Economy and the Modern Industrial Imaginary", en Liberalism and the origins of the Social: Women, Poberty, and the Political meanings of Philanthropy in Nineteenh_Century. Spain (A dissertation for the degree of Doctor of Philosophy, University of Michigan), 2008, pp. 78-102.

${ }^{8}$ James Bowen, Historia de la educación occidental. T. III: El Occidente Moderno, op. cit., 483-485.
} 


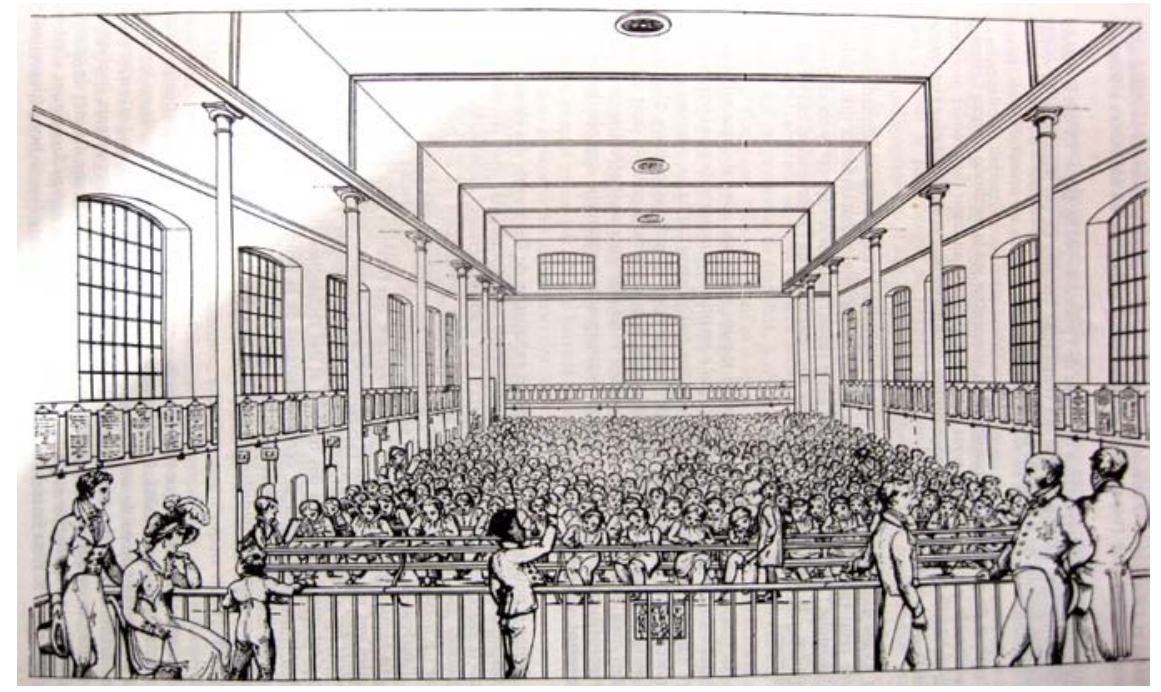

6.- Gran salón de escola mutua ou lancasteriana urbana, 1816

Convén entender desde os anteriores supostos a Lei Guizot de 1833, que declaraba a instrución universal como garantía de orde e de estabilidade social. En $1815^{9}$ no mesmo escenario francés, seguindo unha práctica inglesa, creárase a Societé pour l'instruction élémentaire, da que igualmente Saint-Simon formara parte, que quería promover a instrución dos indixentes, sen poñer en cuestión a orde social ${ }^{10}$. En canto á educación infantil, baixo a influencia de Robert Owen, traducido en francés en 1825, Denis Cochin ${ }^{11}$, autor en 1833 dun Manuel des salles d'asile, acertou a orientar a expansión das "salas de asilo": en 1836 había xa 24 en París, con control público do Comité Central de Instrucción Pública, e 102 en toda Francia. Estaban imbuídas de rasgos de filantropía e de beneficencia, ao estar destinadas ás infancias pobres, e comezaba a haber algunha preocupación pola educación das nenas, a beira dalgúns falangsterios.

Esta preocupación pola educación estaba presente noutros escenarios europeos, suscitándose por iso, non só formulacións sobre as finalidades da instrución e da educación, como as de Kant, senón tamén propostas e realizacións prácticas, como as da ensinanza mutua ou lancasteriana, ou as derivadas do chamado "sistema intelectual”, con Pestalozzi como un dos seus definidores, conformándose dúas

\footnotetext{
${ }^{9}$ Maurice Gontard, L'enseignement primaire en France. De la Revolution a la loi Guizot (1789.1833). Des petites écoles de la monarchie d'ancien regime aus écoles primaires de la monarchie bourgeoise (París: Societé d'Edition "Les Belles Lettres", 1959)

${ }^{10}$ François Mayeur, "De la Revolution a 1'École Republicaine”, en Louis-Henri Parias (Dir.), Histoire Générale de l'Enseignement et de l'Éducation en France (París: Nouvelle Librairie de France, 1981): 106-107.

${ }^{11}$ Alcalde do 12 arrondissement, que como De Gerando visitou as infant-schools de Londres.
} 
perspectivas: a tradición británica do sensoempirismo, de orientación utilitarista, e a alemana (kantiana), idealista, que acentuaba a orientación moral ${ }^{12}$, como fundamental finalidade da educación, desde o seu interese por construír un mundo moral e rexenerado. Podían ser percibidas as influencias de Locke, por unha parte, e de Rousseau, pola outra. O Philantropinum de Basedow ${ }^{13}$ abrirá unha ruta, que Kant iba a ter en conta, na que se identificaba a educación como aprendizaxe cognitiva e moral (a Bildung neo-humanista), que implicaba o cultivo das facultades mentais (en particular, da razón) coa contribución de actividades prácticas $^{14}$. Despois de Kant o enfoque idealista da educación sería expandido por Pestalozzi e por Herbart, até o punto de impregnar a maior parte do pensamiento e a práctica educativa continentais no século XIX.

Pestalozzi, partidario do desenvolvemento intelectual analítico e sensoempirista, a través da observación intuitiva ${ }^{15}$ dos fenómenos, apuntou ao mesmo tempo ao crecemento moral (como a adquisición dunha conciencia da harmonía; é dicir, conciencia da interrelación e interdependencia de todos os fenómenos da natureza en canto que totalidade orgánica básica da vida ${ }^{16}$, desde a metáfora orgánica do desenvolvemento natural, o que supoñía partir das compoñentes sensoriais máis simples do coñecemento, até acadar unha posición holista, tendo presente a visión holista da natureza como un sistema completo, integrado e cun fin espiritual determinado. Así, indicaba que a ensinanza debía efectuarse partindo do concreto (percepción e palabra formando un todo integral), procedendo gradual e secuencialmente, seguindo a orde da natureza, discernindo cada paso mediante preguntas, para desde as respostas correctas poder construír conceptos abstractos xerais. Ao coñecemento na súa dimensión sensible debería dárselle "forma intelectual": é dicir, proceder a entender as formas do sensible, coñecer os seus nomes e saber separar as distintas unidades das cousas aprezadas sensiblemente a través da intuición, mediante un despliegue simultaneo de aptitudes.

Deste modo, a ensinanza da lectura habería de realizarse desde a comprensión dos significados das palabras mediante exercicios simples, fáciles e divertidos; tamén, mediante imaxes e con exercicios variados. Con tal preocupación, as

\footnotetext{
${ }^{12}$ Que abría paso á educación da vontade e do obrar.

${ }^{13}$ Houbo alí unha preocupación singular por dispoñer as aprendizaxes, mediante a presentación das actividades cognitivas de modo secuenciado, a implicación organizativo-didáctica dos docentes para facer as leccións o máis agradables e variadas posible, ou a presenza de xogos e outras vías de participación dos estudantes.

${ }^{14}$ James Bowen, Historia de la Educación Occidental. T. III. El Occidente Moderno, op.cit, 282-283.

${ }^{15}$ A observación intuitiva, algo distinto do puro sensualismo, sostén Caruso, permitiría dar paso ao que poderíamos dicir vibración singular do espírito: o materialismo inscrito na natureza sensoempirista (o "afora", o exterior), que significa a predominancia das sensacións na aprendizaxe debía entrelazarse cos "adentros", o interior, o espírito do suxeito, camiñándose así cara a "espiritualización da pedagoxía, como coidadamente sinalou Marcelo Caruso, "El fin del sensualismo. La pedagogía alemana en el primer normalista español (1840-1860)", en José Ma Hernández Díaz (Coord.), La pedagogía alemana en España e Iberoamérica, 1810-2010, (Valladolid: Castilla Ediciones, 2010): 54.

${ }^{16}$ Ibid., 301.
} 
escolas que seguiron o sistema intelectual dividíronse en catro graos, clases o seccións: preparatoria (de 5 a 7 anos), elemental (de 7 a 9), media (de 9 a 11) e superior (de 11 a 12 anos), extendéndose os programas ao longo destas clases:

"Todo se fai por demostración nos encerados, sobre os que se trazan con xiz exemplos de escritura, así como os exercicios relativos ao estudo da lingua, da aritmética, e do canto. (...) Neste sistema, alén da fermosa escritura, os nenos aprenden a calcular ben, a ler con xuízo e gusto, a coñecer as regras da súa lingua, a redactar... Os mestres son homes experimentados, instruídos a fondo, con coñecementos; mozos novos que fixeron proba de talento para o ensino. É certo que o mantemento dunha destas escolas é máis caro, pero a formación recibida é mellor, e tamén os alumnos teñen máis libros de lectura e cadernos de papel en lugar de "pizarras" (ou lousas). (...). Todos os libros que se poñen entre as súas mans...reafirman leccións e exemplos de virtude, de sabedoría e de submisión aos seus superiores. Aos nenos dos campos fálaselles dos seus campos, dos froitos, dos xardíns, dos bosques, do carbón, das vacas...; da condición e estado do traballador; fáiselles ver a súa bondade e os servizos que renden á súa patria...; e apréndese a bendecir á Providencia, facéndolles ver a fermosa natureza que cultivan. Aos nenos burgueses das cidades fálaselles de cousas más elevadas; aos nenos dos indixentes fálaselles do traballo, da bondade, das leis, da súa patria..., e a todos, da moral e a relixión. Dase unha atención particular ao ensino da lingua do país, non coa intención de transformar aos nenos da clase indixente, de campesiños e de pequenos burgueses en eruditos ou en gramáticos, senón a fin de exercitar o seu xuízo e de acostumalos a captar o espírito do que aprenden, pois nada é, en efecto, máis propio para formar o xuízo dos nenos, que o estudo razoado dos principios da lingua. Ocorre o mesmo coas matemáticas" ${ }^{\prime 17}$.

Era parcialmente diferente a orientación escolar reformadora inglesa. Fronte á tradición, suscitábase a conveniencia racional e utilitaria da extensión da educación. Cómo levar a cabo a educación de importantes colectivos infantís, sendo conscentes da escasez de recursos para iso? A resposta foi dada desde a redución do programa escolar aos aspectos "instrutivos" (lectura, escritura e aritmética, con costura para as nenas), apostando por un sistema xerarquizado de monitores (alumnos axudantes con distintos encargos), cunha organización en "clases" de similar nivel dentro da aula, mediante a disposición de salas amplas con fileiras de bancos, constituíndo cada unha unha "clase", con semicírculos ao longo das paredes laterais e a edición de libros e de materiais didácticos graduados para as distintas clases e diversas aprendizaxes, así como co uso das lousas. A expansión destas escolas mutuas, sendo inicialmente notable, porén, pareceulle a moitos un sistema maquinal, dada a aplicación mecanicista coa que polo xeral interviñan os alumnos monitores, en ausencia dunha superior formación como a

\footnotetext{
${ }^{17}$ Charles Jérôme Van Nerum, Essai sur l'instruction primaire et en particulier sur les écoles gratuires de Gand. Gand: Chez Annoot-Braeckman, Imprimeur de la Ville, 1838, 111-120.
} 


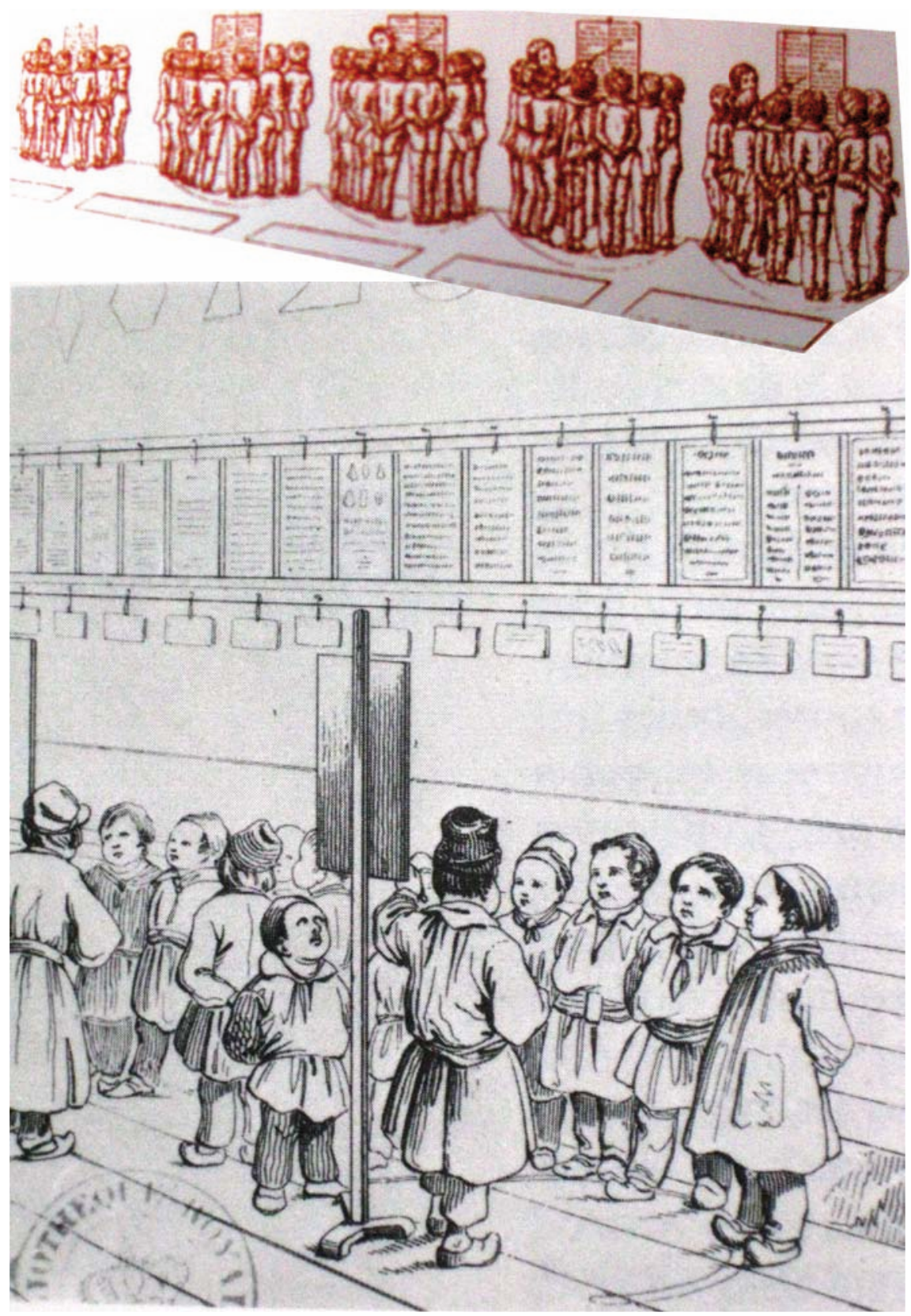

9, 10.- Actividade de aprendizaxe (alumnos e alumnos-instrutores) 
que se esperaría dun profesor; un sistema que podendo ser de alguna utilidade nos ensinos elementais, non valía para todas as disciplinas escolares, nin tampouco para a "educación moral".

Pola súa parte, os Hermanos de las Escuelas Cristianas de La Salle avanzaran un sistema de "ensinanza simultánea" (os alumnos reunidos en "clases" reciben a lección conxuntamente do profesor) en aulas separadas. Ademais, o progresivo maior número de docentes, que existía cara aos anos corenta do século XIX, abría a posibilidade de prescindir dos monitores, a favor dos profesores axudantes ou alumnos-normalistas auxiliares, no caso dos grupos de aula numerosos, que así completaban a súa formación, sendo deste modo posible levar a cabo unha metodoloxía docente senón simultánea e en aulas separadas, cando menos "mixta", en lugar da práctica do método lancasteriano ou mutuo.

\section{Ramón de las Sagra (1798-1871): observador e teórico social}

Paga a pena que coñezamos os rasgos biográficos máis notables ${ }^{18}$ de quen se convertiu nun privilexiado observador do laboratorio parisino; alguén que facía gala de positivismo científico, que non eludiu participar nos debates sociais do momento e alguén que depositaba unha razoable confianza na educación como instrumento de reforma social ${ }^{19}$. É unha figura que posúe un recorrido vital moi amplo, no que hai estudos, viaxes, actividade política, iniciativas de creación de prensa escrita, edicións en diversos países, controversias, actividade empresarial, correspondencia internacional...: naturalista, sociólogo, economista, comparatista, teórico social e político. Manifestou interese polo escolar, desde os días en que en América (1835) tiña recorrido escolas e outras institucións sociais. Faise evidente nos seus textos sobre as visitas xiradas en Bélgica, en Holanda e en Alemania,

\footnotetext{
${ }^{18}$ A reconstrución biográfica toma en consideración, en particular, as referencias seguintes: Emilio González López, D. Ramón de la Sagra: naturalista, historiador, sociólogo y economista (A Coruña: Caixa Galicia, 1983); Ascensión Cambrón Infante, Ramón de la Sagra, el poder de la razón (A Coruña: Vía Láctea, 1994); Baldomero Cores Trasmonte, Ramón de la Sagra (Santiago: Xunta de Galicia, 1998); Baldomero Cores Trasmonte, Ramón de la Sagra e Galicia (A Coruña: Publicacións da Deputación da Coruña, 2003); Mónica Burguera, Las damas del liberalismo respetable. Los imaginarios sociales del feminismo liberal en España [1834-1850] (Madrid: Cátedra, 2012), cun amplo detemento na figura de La Sagra.

${ }^{19}$ Algunhas das referencias máis notables, sobre La Sagra como teórico social poden ser as seguintes: Manuel Núñez de Arenas, "D. Ramón de la Sagra, reformador social”, Revue Hispanique (Tours), LX, (1924): 329-531; Juan Maluquer de Motes y Bernet, El socialismo en España,1833-1868 (Barcelona: Crítica, 1977); Antonio Elorza, Socialismo utópico español (Madrid: Alianza 1970); Emilio González López, D. Ramón de la Sagra: naturalista, historiador, sociólogo y economista (A Coruña: Caixa Galicia, 1983); Ascensión Cambrón Infante, El socialismo racional de Ramón de la Sagra (A Coruña, Deputación Provincial, 1989); Ramón Carballal Pernas, Ideario político-social e penitenciario de D. Ramón de la Sagra (Academia Gallega de Jurisprudencia y Legislación: A Coruña, 1976); Luis González Guitian, Ramón de la Sagra: utopía y reforma penitenciaria (Sada: Ediciós do Castro, 1985); María José Lacalzada de Mateo, Concepción Arenal. Mentalidad y proyección social (Zaragoza: Prensas Universitarias de Zaragoza, 2012).
} 
entre 1838 y $1843^{20}$, comasí na súa implicación académica e discursiva, a prol das primeiras iniciativas hispanas de creación de escolas infantís.

Ramón de la Sagra Períz (1798, A Coruña), despois de realizar estudos primarios e outros (probables) de matemáticas, navegación e debuxo técnico nas aulas do Consulado do Mar da Coruña, pasará ao Colexio Militar de Cadetes da cidade de Santiago a ao Real Colexio de Farmacia, antes de trasladarse a Madrid a finais de 1818, probablemente debido aos problemas derivados da súa militancia masónica; solicita trasladarse a Alcalá de Henares coa intención de examinarse para poder "ingresar en el Real Cuerpo de Ingenieros".

Aquí comeza a colaborar en El Constitucional, o sea Crónica Científica, Literaria y Política, que dirixía o masón José J. Mora. En 1820 participa alí con outros liberais doceañistas na fundación do Ateneo Español, instancia que desaparecería ao pouco tempo, sendo recuperada en 1835. En 1823 volve por segunda vez a La Habana en calidade de catedrático de historia natural adxunto ao recén creado Xardín Botánico, e deseguida ocupa a cátedra de botánica agrícola da Escola de Agricultura da Sociedade Económica de Amigos do País de La Habana, sendo nomeado tamén director do Xardín Botánico, que organizou cunha doble atención médica e agrícola. Nel, como nos campos da mineraloxía e da xeología, realizará unha ampla actuación científica, manifestándoo mediante a formación de coleccións, a difusión por toda a illa de tecnoloxías aplicables aos cultivos, así como mediante diversas publicacións, sendo nomeado membro de distintas Sociedades e Academias, como a Linneana de París, a de Física e de Historia Natural de Xenebra, a de Ciencias Naturais de Filadelfia ou a do Museo Real de Historia de París. Entre 1827 e 1831 funda e dirixe en La Habana os Anales de Ciencia, Agricultura, Comercio y Artes $^{21}$, ao servizo da modernización industrial e da agricultura, manifestando xa a súa preocupación pola educación ${ }^{22}$; ao tempo, mantén correspondencia con figuras como Lagasca, Cavanilles, Alexander von Humboldt e Auguste De Candolle, e publica en 1831 a Historia económica, política y estadística de la Isla de Cuba. Tamén en Cuba coñece as ideas do

\footnotetext{
${ }^{20}$ Fixemos un tratamento parcial da súa figura en Antón Costa Rico: "Ramón de la Sagra: en los albores de la educación infantil en Europa. Lecturas y precisiones”, en Luis Naya Garmendia, y Pauli Dávila Balsera (eds.), La infancia en la historia. Espacios y representaciones (Donostia: Erein, 2005, vol. II, 482-495; "Ramón de la Sagra. Un protosocialista hispano ante el desarrollo educativo", Revista Española de Historia, num. 228, (2008): 193-210; http://hispania.revistas.csic.es/index.php/hispania article/viewArticle/78 (consulta: 10-01-2013 e " Sociedad burguesa y educación en el siglo XIX: la perspectiva reformista transnacional de Ramón de la Sagra y la educación en España”, Bordón, 65, (4): 47-60. Remitimos a estas achegas para maior precisión de notas críticas.

${ }^{21}$ Desde 1830 esta cabeceira será cambiada pola de Anales de Agricultura e Industria Rural.

${ }^{22}$ Véxanse, por exemplo: "Noticia sobre las escuelas de industria establecidas en Inglaterra, y sobre los libros destinados para ellas" (T.I., setembro 1927, 85-89); “Tareas de la Real Sociedad Económica de Cádiz" (sobre la escuela lancasteriana de Cádiz), (T.I., outubro 1928, 47-50); "Idea del establecimiento agrónomo fundado en Hoffwil por M. de Fellemberg”(outubro, 1831, 305-310).
} 


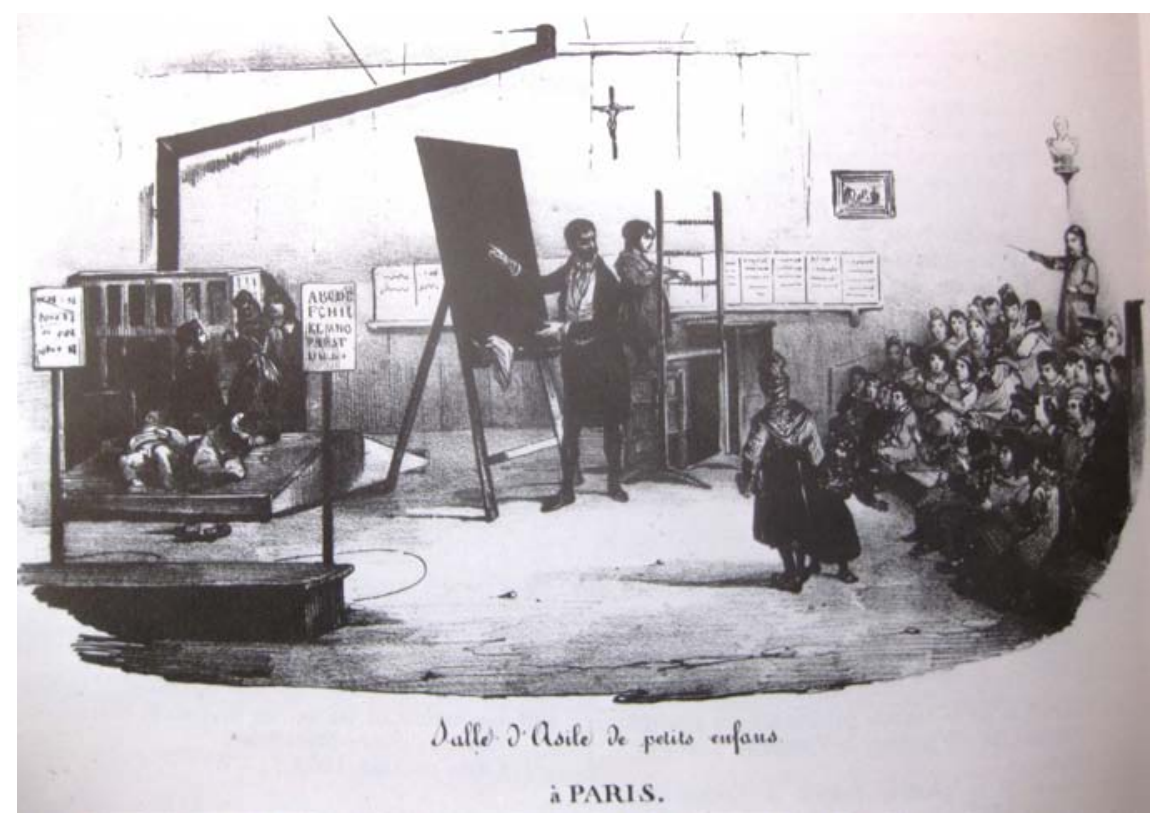

11.- Sala de asilo ou aula de educación infantil en París (circa, 1830)

"socialismo racional" do belga e sansimoniano barón de Colíns, polas que se sentirá influenciado.

En 1835, antes de regresar a Europa, viaxa durante cinco meses polos Estados Unidos, para estudar as cuestiones sociais ao considerar que o home moral debía ser o primeiro obxeto das súas observacións. Recorre as cidades de New York, Filadelfia, Washington e Boston, visitando centros científicos e museísticos, establecementos benéficos (orfelinatos, escolas de cegos e de xordomudos,...), cárceles, centros de ensinanza primaria e outros para a formación de artesanos e toma contacto con distintas personalidades, de todo o cal deixaranos unha interesante memoria.

En París residirá desde o outono de 1835, en calidade de Agregado honorario á Embaixada española, aproveitando esta estadía para levar a cabo a edición -baixo a protección gubernamental española- da Historia física, política y natural de la Isla de Cuba, en doce tomos, editados entre 1838 e $1857^{23}$, cunha complementaria

\footnotetext{
${ }^{23}$ Oito deles editados na casa editorial parisina Arthus Bertrand e catro en Madrid. Pola súa ollada omnicomprensiva e integradora dos feitos naturais e sociais ten sido considerado un epígono de Alexander Humboldt. Os estudosos deron conta da complicada edición desta magna obra con textos e imaxes, sobre todo de historia natural, da que se fixeron dúas edicións, en castelán e en francés, que apareceron en primeira instancia a modo de cadernos. Estes doce volumes amplíaronse coa edición dun Atlas Geográfico de la Isla de Cuba, e un último suplemento aparecido como número XIII en 1862. Existen textos previos con similar título, editados a modo de grandes fascículos, desde 1837, además dunha
} 
un medio para telas tamén algún dia, dominoume a idea de visitalas e reunir cantas noticias útiles fose posible"25.

No mesmo ano publica o folleto Des établissements de bienfaisance a Madrid (París, 1838), como mostra da súa preocupación pola protección social da infancia, e nesta dirección en 1839, ano no que recibe o título de doutor pola Universidad de Santiago de Compostela, pronuncia o discurso de fin de exames anuais do Colexio de Xordomudos de Madrid ${ }^{26}$, ademáis de ser electo vicepresidente da recén creada "Sociedad para la mejora del sistema carcelario". En 1840, entre outras actividades, entre as que cabe destacar a creación da "Sociedad para la mejora del sistema carcelario, correccional y penal”, pronunciará no Ateneo seis conferencias sobre economía social ${ }^{27}$, con referencias á promoción dos intereses materiais e morais dos sectores populares, a Krause e á obra Cours de droit naturel ou de la philosophie du droit de Mr. Ahrens, unha reflexión sobre o Estado, a sociedade e a política, pronunciándose contra a constitución liberal da propiedade territorial e a prol da propiedade colectiva.

Entre tanto, La Sagra exercía como inspector da escola de párvulos da rúa de Atocha e editaba o contiño Antonio y Rita o los niños mendigos ${ }^{28}$, alén de intervir na creación das Escolas da Fábrica Nacional de Tabacos (sala de aleitamento e asilo de cigarreiras). Desde xaneiro de 1842 dirixe en Madrid a Escola de Artesanos creada polo Instituto Español, como manifestación do seu interese pola educación de adultos ${ }^{29}$.

\footnotetext{
${ }^{25}$ Ramón de la Sagra, Relación de los viajes hechos en Europa bajo el punto de vista de la instrucción y beneficencia pública, la represión, el castigo y la reforma de los delincuentes, los progresos agrícolas e industriales y su influencia en la moralidad (Imprenta de Hidalgo, 1844, T. I, VIII).

${ }^{26}$ Discurso leído por D. Ramón de La Sagra el día 29 de diciembre de 1839 al terminar los exámenes de los alumnos..., S.1., S.a.

${ }^{27}$ Ditas conferencias, entre as que unha foi para a cuestión educativa ("La influencia de la instrucción superior prodigada a las masas"), publicáronse nunha obra unitaria (Ramón de la Sagra, Lecciones de Economía Social, [Madrid: Imp. de Ferrer y Cía., 1840]), centráronse no tratamento dos "remedios contra los males sociales": o fomento dos intereses materiais, a instrución e a educación, a beneficencia pública, o castigo e a represión dos delitos e crimes, e a reforma moral dos individuos e delincuentes. Unha manifestación global da intervención filantrópica en favor da reprodución moral da orde social burguesa, para o que incorporaba a educación racional das mulleres.

${ }^{28}$ Madrid: Imprenta del Colegio de Sordomudos, 1840, 30 p. Na obriña referida ao traballo infantil nas manufacturas textís de Cataluña facía unha reflexión sobre os abusos sufridos polos nenos no traballo industrial.

${ }^{29}$ Ramón de la Sagra, Discurso leído el 2 de Enero de 1842 en la apertura de la Escuela dominical para artesanos (Madrid: Cía. Tipográfica, 1842).
} 

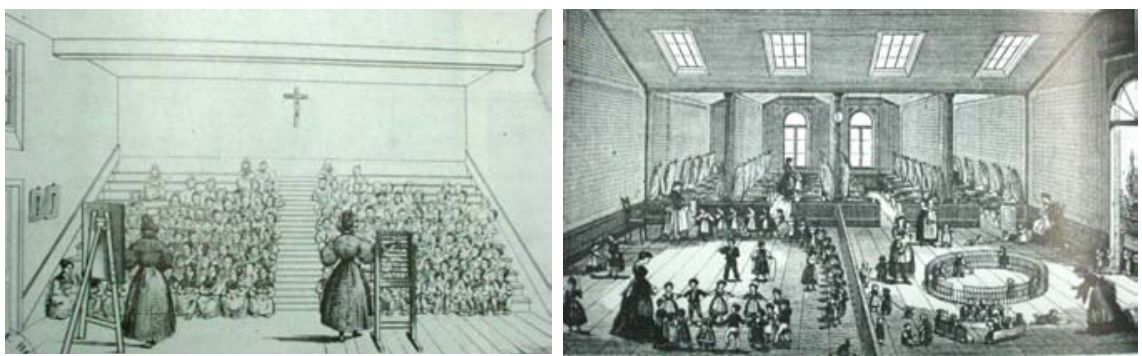

13.- Dobre sección para nenos e para nenas nunha sala de asilo / Sala de asilo modelo para xogos, cantos e descanso. Anos corenta do sec. XIX

No outono de 1843, ao quedar paralizados diversos proxectos sociais emprendidos baixo a rexencia de Espartero, La Sagra viaxará outravolta por Francia, Bélxica e Alemania. A Bélxica, a cuarta vez que alí vai ${ }^{30}$, acompañarao o director do colexio de xordomudos de Madrid, Juan Manuel Ballesteros, a quen La Sagra lle sirve de introdutor ${ }^{31}$, ademais de visitar a Ducpetiaux ${ }^{32}$ e a Arhens. Ao seu regreso a Madrid, emprende La Sagra en 1844 a dirección da Revista de los intereses morales y materiales. Nela poñerá de relevo un ideario filosófico e social encadrable no movemento proto-socialista; alí aparecen algúns escritos sobre instrución pública e criminalidade en Inglaterra e Francia, o traballo infantil nas minas inglesas ${ }^{33}$ e a mortandade dos nenos expósitos en Madrid. En 1845 volverá, brevemente, ao

\footnotetext{
${ }^{30}$ Pois tamén estivera en 1841 como delegado gobernamental español na Exposición industrial, ocasión de preparación do Informe sobre el estado actual de la industria belga con aplicación a España.O informe desta viaxe quedou plasmado pola súa parte en Notas de viaje escritas durante una corta excursión a Francia, Bélgica y Alemania en el otoño de 1843 , Madrid, Imp. de la Guía del Comercio, 1844.

31 "Presentaba al amigo Ballesteros en los establecimientos de mudos y ciegos, estudiando con detención los métodos, adquiriendo los utensilios necesarios para organizar bien estas enseñanzas en España, que era otro de los objetos de mi viaje", dice La Sagra en la p. 108 de sus Notas de viaje escritas durante una corta excursión..., op.cit. Ven ao caso anotar que o médico Juan Manuel Ballesteros, director del Colexio de Xordomudos e Cegos de Madrid era xa unha personalidade relevante neste campo, no que foi autor de obras notables.

${ }^{32}$ Edouard Ducpetiaux (1804-1868) foi un destacado reformador social belga, tamén afecto ao krausismo, estudoso da condición social das clases obreiras en Bélxica e autor, entre outras obras, de Enquete sur la condition des classes ouvrieres et sur le travail des enfants en Belgique (1848). La Sagra refírese nas citadas Notas de viaje escritas... (70-71) a unha obra previa escrita por Ducpetiaux sobre a condición física e moral dos rapaces obreiros (Bruselas, 1843), que era unha documentada obra en tres libros que reunía todas as observacións que serviron para iniciar un proceso de reforma da lexislación laboral sobre as mulleres e os nenos en Bélxica. Nas súas últimas páxinas “contiene -dí, La Sagra-el proyecto y el reglamento de que habíamos hablado el año anterior, para una asociación humanitaria entre los hombres pensadores de todos los países, que se ocupan en sondear las llagas del cuerpo social y en buscarles un remedio", pois alí irían converxer os proxectos de reforma para ser sometidos ao crisol da discusión, antes de ser trasladados ao campo da práctica.

33 "Del trabajo de los niños en las minas de carbón de la Gran Bretaña", Revista de los intereses materiales y morales, T. I, 1844, 38-46, tomando como información de partida un Informe inglés, recollido por Ducpetiaux, acompañado con viñetas gráficas alusivas á penalidade de tales traballos: "pasando doce y más horas en la oscuridad terminan en un estado casi de idiotas".
} 


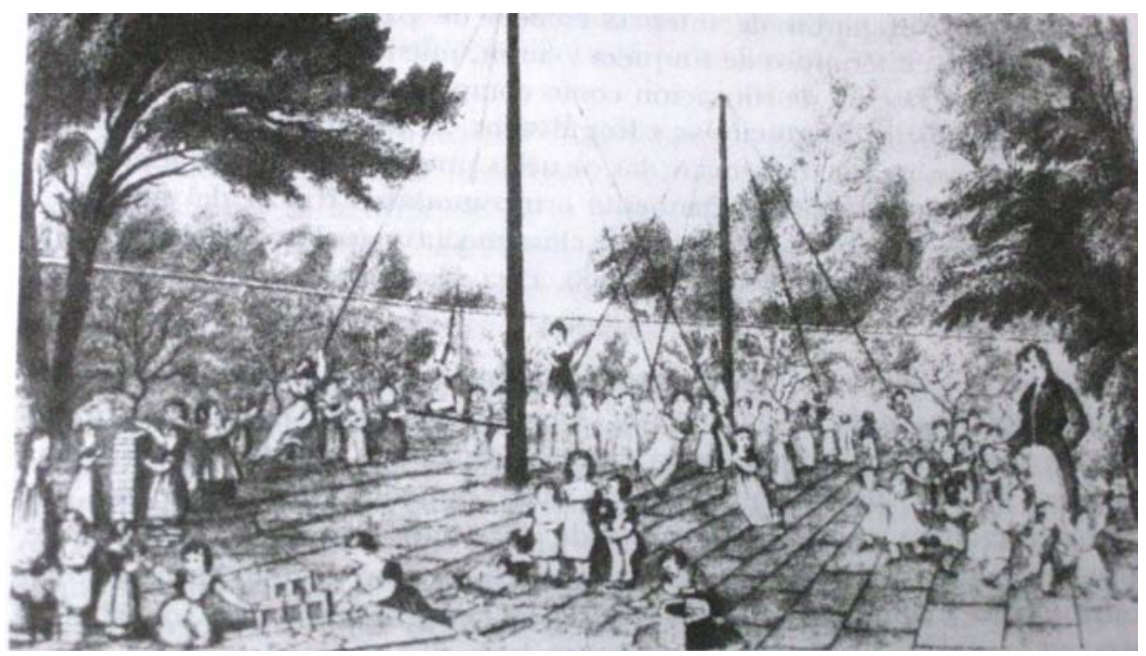

14.- Escena no xardín dunha escola infantil inglesa

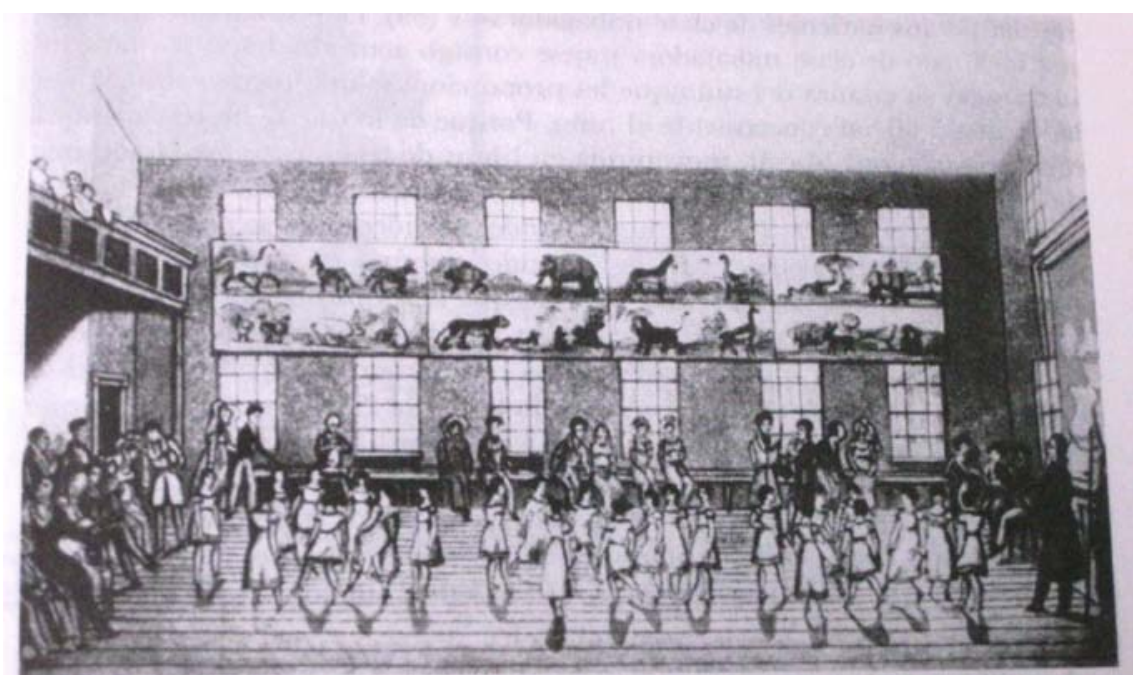

15.- Escena de ximnasia na escola de New Lanark (Escocia), baixo a dirección de Robert Owen

escenario parlamentario, mentres se aproxima ao ideario proudhoniano, pero un ano máis tarde dirixirase novamente a París, onde participará nos grandes debates sociais que alí tiñan lugar. Faino, igualmente, na Academia de Ciencias Políticas e Morais e en relación cos "protosocialistas", que desconfiaban da capacidade do sistema liberal para resolver os problemas sociais e morais, na procura conxunta 


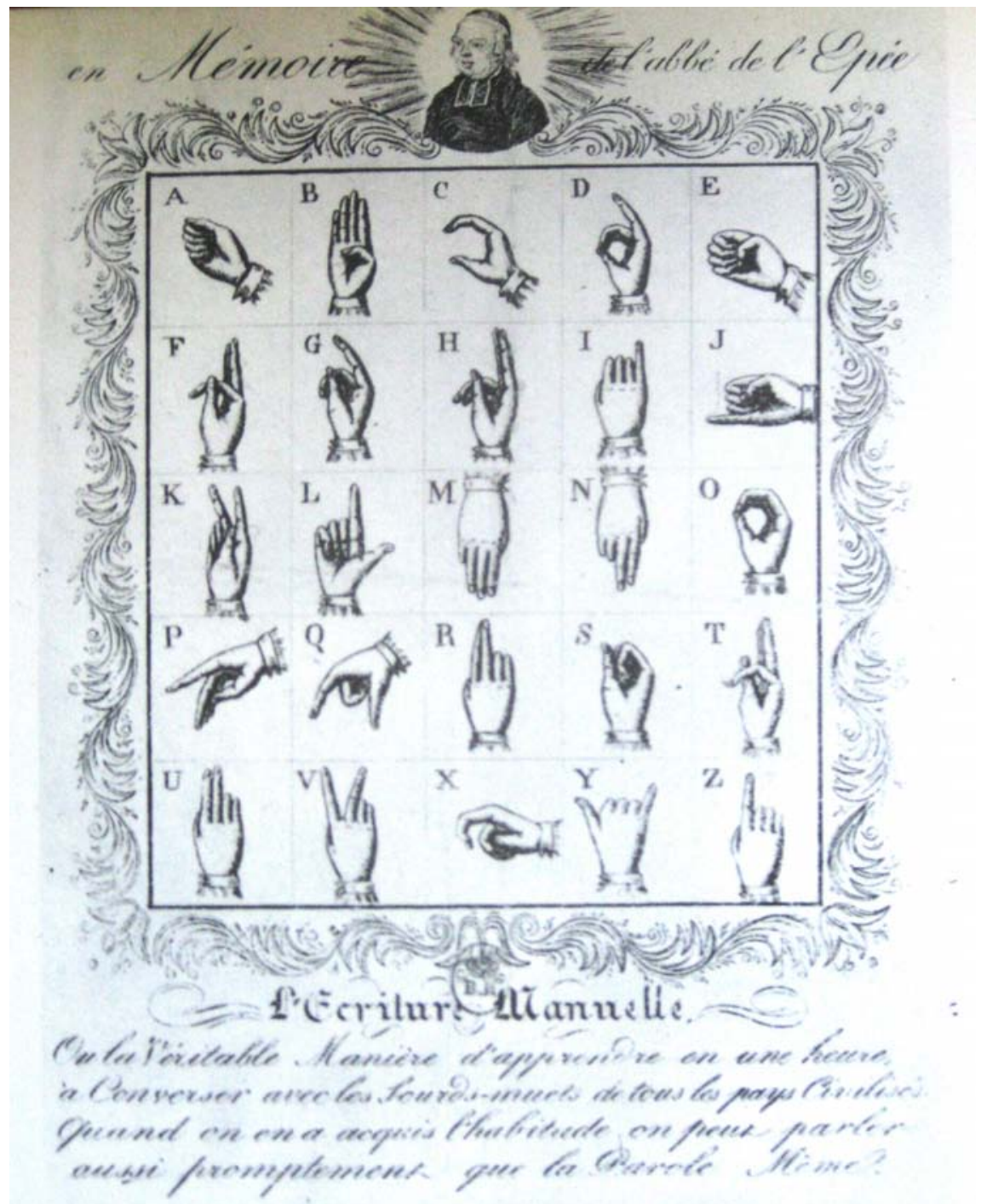

dun sistema social novo. Neste sentido, en 1847 intervén en Bruxelas no Congreso de Economistas, en que se dirimía o librecambio, frente ao proteccionismo estatal ${ }^{34}$,

\footnotetext{
${ }^{34}$ En tal congreso, no que tamén participa Marx, entre outros 177 participantes de 12 países, La Sagra, que o fai en representación das asociacións librecambistas de Madrid e de Cádiz, proclámanse as virtudes do librecambio, como, segundo a mesma tese de Marx, panca que levaría ao incremento do capital produtivo e da mellora económica dos traballadores.
} 
facéndoo tamén no Congreso Penitenciario alí celebrado ${ }^{35}$. Escribe colaboracións no fourierista La Democratie Pacifique, colabora con xornais proudhonianos Le Peuple $^{36}$ e Le Representant du Peuple (1848-1849) e coa La Tribune des Peuples ${ }^{37}$, dentro dun contexto de diálogos con Proudhon, con Louis Blanc, por medio de quén coñece a Engels, e con algúns grupos parisinos de inspiración socialista, arredor da cuestión socialismo asociativo vs. socialismo intervencionista estatal, situándose La Sagra nas marxes da primera posición.

Diante da desigualdade social impoñíase para La Sagra a organización racional do traballo, que esixía, entre otros extremos, "unha instrución gratuita e universal dada a todos" ${ }^{\prime 3}$. En troques, non acepta as posición máis progresivas que os socialistas comezaban a formular, en particular Engels e Marx, nin os riscos de violencia, como os observados con ocasión dos sucesos revolucionarios de 1848 de París, como deixa constancia en 1848 nos seus Aphorismes Sociaux ${ }^{39}$ e regresa a Madrid. Aínda en 1851 visitará a Exposición Universal londinense como enviado gubernamental e como xurado, traendo candasí diversos obxectos para formar en Madrid un museo industrial ${ }^{40}$, mentres publica artigos de divulgación científica en La Nación, periódico progresista constitucional que en Madrid dirixía o compostelano Rúa Figueroa ${ }^{41}$. En 1854, ano en que funda en París El Eco

\footnotetext{
${ }^{35}$ Neste Congreso Internacional de Beneficencia e Prisións, celebrado coa participación de representantes de catorce Estados, entre eles España a través de Ramón de la Sagra, tomouse o acordo de fundar unha "Asociación Internacional de Caridade", sobre a base da "Sociétè d'Economie Charitable", que inicia a súa actividade en 1848, xunto á revista Annales de la Charité fundada en París, en 1845, como órgano de difusión. No Comité central da Societé estarán Ducpetiaux, Suringar, La Sagra, como "philantrope chretien", e M. Chevalier, fourierista y sansimoniano, que conocera a La Sagra nos EEUU en 1835. A obra que pretendían era a de arbitrar institucións de beneficencia e promover reformas sociais legais, á marxe das loitas políticas e relixiosas.

${ }^{36}$ En decembro de 1848 aparece o seu primeiro artigo en Le Peuple. Journal de la Republique Democratique et Social. Os artigos de Le Peuple reuniunos nun libro en 1849 co título Banque du Peuple. Théorie et pratique de cette institution fondée sur la doctrine rationelle (Bureaux de la Banque du Peuple: París), presentando o Banco como un proxecto con finalidade humanitaria e un novo código do mecanismo económico coa perspectiva da reforma social integral.

${ }^{37} \mathrm{O}$ reformador ruso Alexandre Herzen que escribiu extensas memorias sobre a súa estadía en París naquelas datas, así o recolle, mediante unha intervención do español La Sagra iniciada cun "Je demande la parole", intres antes da saída á rúa do xornal. Alexandre Herzen, El pasado y las ideas (Barcelona: El Aleph, 2013): 482. Un exame dos 32 primeiros números, consultados na Bibliotheque National de France, permítenos ollar as colaboracións de La Sagra, que se producen nos números 1, 5, 7, 12, 31 e 32 .

${ }^{38}$ Ramón de la Sagra, Banque du peuple, op. cit., 97.

${ }^{39}$ Este texto coñeceu a súa primeira edición en España (Aforismos sociales) en 1844. A edición francesa fíxoa en 1848: Le mal et le renmede. Aphorismes sociaux. Profession de foi, (chez l'Auteur) vertendo unha doctrina esencialmente relixiosa e un enfoque científico espiritualista en contra do materialismo. A edición definitiva será a de 1859 , na casa parisina Germer Baillère.

${ }^{40}$ Deixará constancia en Memoria sobre los objetos estudiados en la Exposición Universal de Londres y fuera de ella bajo el punto de vista del adelanto futuro de la agricultura e industria española (Madrid: Imprenta del Ministerio de Fomento, 1853).

${ }^{41}$ Con colaboracións similares ás que viña publicando en francés en La Presse e en Le Journal des Debats, de París.
} 
Hispano-Americano, consigue (parece que por razón de subsistencia e da man dos Vázquez Queipo) acta de Deputado por Lugo polos Unionistas de O’Donnell, dentro da súa deriva cara un pensamiento conservador e temeroso da anarquía social, non exento, porén, de idealistas posicións de reforma social. Trasládase de novo a París en $1856^{42}$ abandonando as perspectivas da reforma social, en favor de reflexións que apuntaban á superioridade da orde moral relixiosa sobre a forza da razón e o progreso material, tal como deixa constancia en diversas contribucións criticadas desde círculos progresistas ${ }^{43}$.

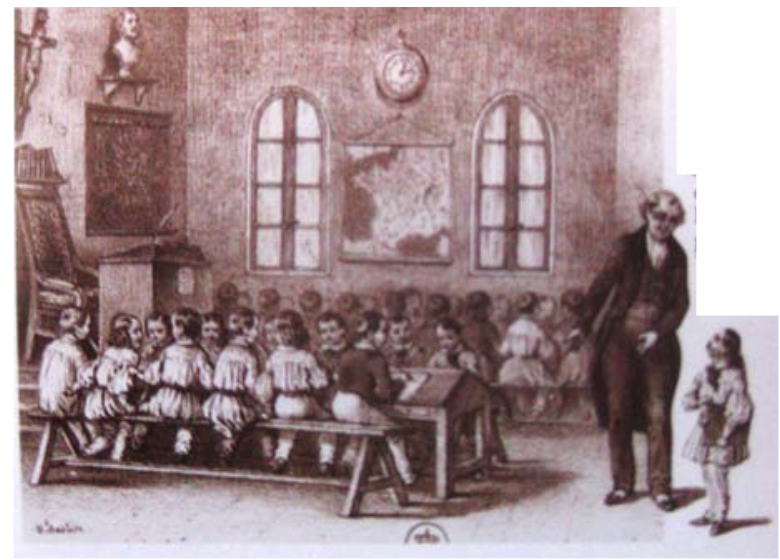

17.- Sala de clase. Francia, 1843

En 1859 volve a Cuba por un período de dez meses, o que lle permite actualizar os seus estudos sobre Cuba, con varias publicacións, en especial Cuba en 1860 e numerosos artigos na prensa cubana, sendo ocasión para que poida inaugurar a primeira escola de párvulos da illa ${ }^{44}$. Ao regresar a París participa na Societé Statistique de París, entre outras actividades. Vive en Madrid no período 1865 a 1867; en 1866 foi nomeado membro dunha Comisión Oficial ("Junta de Información") española para propoñer reformas en Cuba e Puerto Rico e maniféstase contrario con aspectos da política esclavista. Neste mesmo ano traduce ao castelán o groso libro de texto de B. Boutet de Monvel Nociones de fisica ${ }^{45}$, e aparece como colaborador habitual de La Solidarité, un mensual

\footnotetext{
${ }^{42}$ Desde onde envía artigos de divulgación científica ao xornal liberal democrático de Vigo, La Oliva. ${ }^{43}$ Reafírmao na serie periodística "El socialismo en España" publicada en 1858 en La Esperanza; rexeita a súa adscrición a calquera escola socialista, sinalando como autodefinición que "en su juventud había sido en el orden religioso, materialista; en el orden político, liberal democrático; en el orden económico, también liberal, y en el orden filosófico, racionalista", confiando nunha razón fachéndosa, que "casi le había llevado al abismo" (Guitian, op. cit., 183). En 1859 renegará expresamente do racionalismo, pasando así definitivamente ás fileiras do neo-catolicismo.

${ }^{44}$ Ramón de la Sagra, Discursos leídos en la inauguración de la escuela de Párvulos (Habana: 1860).

${ }^{45}$ París: Librérie Hachette, 1866, con numerosos grabados.
} 
de filosofía racionalista, de librepensamento e de loita pola emancipación das mulleres, dirixido desde París, e máis tarde desde Bruxelas, por Ch. Fauvety.

En medio da cada vez máis aguda problemática social, que levaría á Comuna de París en 1871, parece que andaron con algún anonimato os días últimos de La Sagra. En outubro de 1870 trasladaríase a Suiza, desde onde enviou colaboracións para o Diario de la Marina de La Habana, mentres vivía na casa de Hugentobler en Cortaillod (Neuchâtel), amigo e propagador das ideas sociais de Colins e alí morrería La Sagra o 25 de maio de 1871. A pesar de colocarse unha lápida na súa tumba, co tempo perderíase e igualmente os rastros documentais dos seus últimos anos e a súa estimable alta correspondencia ${ }^{46}$.

Morría un personaxe complexo; un racionalista e un idealista, da escola cristiana de Villeneuve-Bergemont, que nun curto período de vida asume un progresismo social do que máis tarde dimite, para buscar refuxio en posicións relixiosas católicas e conservadoras. Un pensador idealista no escenario das "revoluciones burguesas"; un dubitativo reformador social burgués, que baixo a influenza de seguidores de Saint-Simon (Chevalier, Ducpetiaux, ou o barón de Colins) descarta a beneficencia como medio idóneo para solucionar os problemas sociais, en favor dun progresismo económico que esixía cando menos reformas políticas relacionadas coa lexislación obreira e do traballo, nunha perspectiva oposta ás transformacións socio-políticas e económicas suxeridas desde o socialismo marxista. Un pensador ilustrado e filántropo, cosmopolita que, a pesar de ser defensor da propiedade privada, a libre competencia e a xerarquía social, e de ser contrario á estatalización dos medios de producción, analizou os problemas sociais derivados da forma capitalista de produción, compartindo puntos de vista cos sectores liberais e progresistas, sobre unha base filosófica de tradición racionalista, ainda que a súa preocupación non se situaba tanto na busca da igualdade e da xustiza, canto na recomposición da vida moral dos individuos e da sociedade.

\section{As viaxes de Ramón de la Sagra aos Países Baixos.}

Voltemos sobre as súas viaxes a Bélxica e a Holanda. Permitiranlle coñecer e examinar variadas institucións sociais: cadeas, hospicios, escolas, institutos de cegos e de xordomudos, centros educativos de nenas xordomudas, talleres de traballo, escolas industriais e museos, sempre da man de personaxes ou conocidos, ou recomendados desde París a través dos seus colegas no Institut de France,

\footnotetext{
${ }^{46}$ Javier Teijeiro Bugallo, “Aspectos inéditos de la vida y de la obra de D. Ramón de La Sagra”, Museo de Pontevedra (Pontevedra), T. XXXI (1977): 3-10. Tiven ocasión de revisar na Bibliotheque Publique de Neuchâtel as informacións publicadas a este respecto en Le veritable messager boiteaux de Nêuchatel, de 21 de diciembre de 1873.
} 
como o propio Victor Cousin ${ }^{47}$, quen tiña realizado un previo viaxe a Holanda para o estudo do seu desenvolvemento educativo. Como resultado da viaxe escribirá unha obra chea de descricións e observacións de alto interese sobre o adianto educativo neses dous países, salientando, en particular, a preocupación polas vías formativas de adquisición de hábitos morais nunha idade temperá, como quedará reflectido en dous interesantes libros ${ }^{48}$, editados en francés en París en 1839, e logo editados en castelán en Madrid en $1844^{49}$. La Sagra reclama a instrución pública para mellorar a condición do pobo, seguindo sobre todo o exemplo de Holanda,

\footnotetext{
${ }^{47}$ Víctor Cousin (1792-1872) foi defensor do espiritualismo filósófico, contrario ás correntes positivistas e un liberal reformador, en coincidencia con Krause. Este, que establecera contactos cos sansimonianos, tamén os mantivo con Cousin. Por expresa invitación súa Ahrens acudía desde Bruxelas a París para ditar conferencias e con el e con Cousin La Sagra tivo ocasión de compartir ideas e preocupacións sociais. Con posicións conservadoras e idealistas, aínda que defensoras da ensinanza primaria pública obrigatoria, Cousin foi ministro de instrución pública en 1840 no Gabinete de Thiers, e autor de textos sobre a educación en Holanda e en Alemania.

${ }^{48}$ Ramón de la Sagra, Voyage en Hollande et en Belgique sous le rapport de l'instruction primaire, des etablissements de bienfaisance et des prisons, par..., (París, A. Bertrand Ed., 1839, 2 Tt., 300+364 pp); unha obra que recompoñerá e editará en Madrid en 1844 como Relación de los viajes hechos en Europa bajo el punto de vista de la instrucción y beneficencia pública, la represión, el castigo y la reforma de los delincuentes, los progresos agrícolas e industriales y su influencia en la moralidad, (Imprenta de Hidalgo, 2 Tt, 175+182 pp). Hai tamén unha edición en holandés do primeiro tomo da edición francesa dedicado a Holanda.

Na edición francesa, con case o doble de páxinas que a española e unha similar tipografía e maqueta, a descrición do Voyage non segue a orde de viaxe que comezara en Bélgica, entre os días 18 de maio e 25 de xullo de 1838, como aparece na edición española; establece nos dous tomos (Holanda e Bélxica) a seguinte distribución: I: Estado da instrución pública (política, administración e axentes sociais), unha idea xeral histórica, as salas de asilo (escolas infantís) e as escolas primarias, que considera oportuno presentar. En canto a escolas primarias inclúense as "escolas de pobres", en particular, algún exemplos de escolas privadas, as escolas gratuitas municipais, as Sociedades educativas, as chamadas escolas normais para a formación de profesorado, as de debuxo e de carácter industrial, así como os ensinos de moral e de relixión. II: Establecementos de beneficencia: para socorro dos necesitados (sociedades de maternidade, hospicios de orfos, e para militares inválidos), para diminuir a mendicidade (escolas para nenos e adultos pobres, sociedades do ben público, institucións para xordomudos e cegos, talleres de beneficencia, sociedades de damas, colonias agrícolas), institucións para previr ou evitar a pobreza. III: Presentación de cadeas. Aquí e acolá batúxanse, ademais, algunhas referencias ao traballo infantil, á prostitución, ás escolas dominicais, hospitais e establecementos agrícolas. E todos os apartados son tratados con abondancia de datos estatísticos convenientemente clasificados.

${ }^{49} \mathrm{Na}$ edición española suprímese case por completo a información e consideracións sobre as cadeas, ao tempo que outras ricas descripcións de variadas institucións aparecen aquí adelgazadas: porén, isto non ocorre polo xeral no caso da información sobre as salas de asilo e as escolas primarias. Sinala La Sagra (p. 19, nota1, primeiro tomo da edición española): "cuando yo escribía estos pormenores era en el verano de 1838, después de haber dado a principios del mismo año en Madrid algunas explicaciones sobre las salas de asilo o escuelas de párvulos que había visitado en los Estados Unidos y en Francia con mucho detenimiento. Entonces no eran aún conocidas en España, pero luego se establecieron en la capital y sucesivamente en algunas provincias. El deseo de que se generalicen me hace conservar en esta relación todos los pormenores". O recorrido da viaxe, saíndo de París, transcorre por Lille (Francia), Alost, Gante, Bruselas, Amberes, Liège, Verviers, (en Bélxica), Haya, Zwolle, Groninga, Leeuwarde, Horn, Amsterdam, Rotterdam, Leyde e Gouda (en Holanda), para regresar a París, de novo, a través de Bélgica.
} 
coincidindo co español e reformador Pablo Montesino nesa preocupación pola educación moral.

Achégase ás terras norteñas de Holanda, aquelas que o seu "colega $\mathrm{Mr}$. Cousin" non visitara e La Sagra, nos seus relatos, presenta un cadro extraordinario en canto ao desenvolvemento da educación de párvulos na Holanda visitada ${ }^{50}$, o que, sen embargo, non lle impide mostrar o seu maior aprecio polas salas de asilo francesas ${ }^{51}$. Está moi interesado en coñecer e contrastar os programas educativos que se están realizando nestes dous Estados, con tradicións relixiosas, culturais e políticas parcialmente diferentes, estando moito máis presente o mundo católico, cos centros escolares privados nunha Bélxica, que acababa de depender da administración política holandesa, ao ter accedido en 1830 á súa constitución como Estado monárquico ${ }^{52}$.

A súa ollada é con alguna frecuencia rápida e puramente descriptiva. A presenza de estatísticas é moi notable, en quen representa ao goberno español no Primeiro Congreso Internacional de Estatística celebrado en Bruxelas en 1853. $\mathrm{O}$ comentario é tamén con frecuencia rápido, pero claro e explícito. En medio de tantas páxinas, sobre todo na edición francesa, hai lugar para descripcións demoradas, o que nos permite 'ver' a través da súa mirada como era a disposición das aulas; a diversa metodología didáctica das escolas, ou pestalozziana, o lancasteriana; a organización dunha escola industrial; como se abordaba a ensinanza moral e relixiosa ou a ensinanza do debuxo; como se organizaba un hospicio ou unha aula de música para nenos; que actividades promovía e como se organizaba unha Sociedade para o desenvolvemento da educación, ou como se organizaba e funcionaba unha colonia agrícola para adolescentes e mozos en procesos de reinserción.

\footnotetext{
${ }^{50}$ E oportuno sinalar que en Holanda, baixo o reinado de Luis Napoleón, puxérase en marcha unha grande reforma da educación primaria, á que antes xa contribuíra o ministro da $\mathrm{II}^{\mathrm{a}}$ República Rutger Schimmelpennik. Holanda será para La Sagra "un mundo nuevo", modélico no campo educativo, un mundo onde se da a confluencia de influencias americanas coas pestalozzianas que, neste caso chegaran a través do holandés Dirk van Dapperen, formado en Yverdon co propio Pestalozzi, e a quen La Sagra se refire (Voyage en Hollande..., op.cit., T. I., 57-58 e 66-69), á hora de relatar con pormenor o panorama escolar que ao seu ollar ofrece a cidade de Zwoll.

${ }^{51}$ Nas francesas aprezaba un mellor protagonismo didáctico e formativo dos xogos e das cántigas infantís que, segundo La Sagra, deberían fundirse co estudo nunha unidade e non estar separados, como acontecía en Holanda (Voyage en Hollande..., op. cit., T. I., 79).

${ }^{52}$ Co mapa europeo surxido logo do Congreso de Viena en 1815, os territorios de Bélxica quedarían incorporados á Coroa de Holanda, aínda que o rei Guillerme primeiro de Nassau non conquireu unificar aos holandeses e aos belgas. Isto tivo repercusións no ensino: la maioría gobernamental holandesa era defensora do ensino como función pública e estatal, o que foi rexeitado polos católicos belgas, sendo un dos elementos que provocou a revolta destes, até conquerir instaurar en 1830 un goberno provisorio belga e a independencia política, que se completou en 1831 coa aprobación da Constitución belga, de base electoral censitaria, frente ao sufraxio universal holandés, e que proclamaba, baixo a presidencia do rei Leopoldo I, a liberdade de creación de centros escolares.
} 
La Sagra viaxaba xeneralmente con contactos e cartas oficiais de recomendación, cun programa previo, aínda que como consecuencia de tales contactos aparecen outros, que coas súas suxerencias e invitacións o levan a modificar o programa inicial. A este respecto, a nómina de persoas sinaladas ${ }^{53}$ é notable en número e en ocasións tamén en relevancia, o que nos da idea dun personaxe transnacional, que manexa con soltura o inglés e o francés.

Entre outros, o estatístico Quetelet, con quen visita o Instituto para nenos cegos de Bruxelas; o pedagogo Van Nerum, que dirixe a escola de nenos de Gante; o abate Carton (autor de Sur l'éducation des sourd-muets), visitado en Bruxas en 1838 , onde tiña fundado un colexio de xordomudos, a quen xa coñecía de París a onde Carton fora coñecer o Colexio Real de Cegos, ("al que le dió informaciones americanas sobre el Dr. Howe de Boston, y el me las dió de Inglaterra y Escocia”); o profesor de debuxo industrial De Ville Thiry, autor de Cours élémental de dessin geometrique appliqué aux arts, para uso das escolas primarias e industriais, que acompaña a La Sagra nas súas visitas aos distintos centros de Liexe; o Baron De Gerando, un dos impulsores da Societé d'encouragement pour l'éducation industrielle en 1802, e da Societé pour l'instruction elementail; Zoé Gatti de Gamond, educadora, feminista e fourierista, inspectora de escolas primarias de nenas e de escolas normais de institutrices; o Dr. Howe de Boston, médico comisionado a Europa en 1831 para instruírse sobre os distintos métodos de educación de cegos, que descubriu aquí os de interpretación do movemento dos labios e de vocalización que se empregaban nas escolas alemás, quen en Boston abriu un colexio de cegos e imprimiu libros en relevo, regalándolle exemplares a La Sagra en 1835, con quen sostivo correspondencia e envíos de materiais didácticos; o Xeneral Van der Bosch, fundador das colonias agrícolas, como a de Metray, comenzada en 1818, para a educación de orfos e para a reeducación de delincuentes; o xa citado estudoso da infancia belga Ducpetiaux; Charles Guyot, director do colexio de xordomudos de Groninga, a quen lle deu "información sobre os establecementos de New York, Filadelfia e Boston"; o inspector de escolas de Frisia Van der Plaats, "home cheo de saber e de dedicación, a quen lle din unha porción de detalles curiosos que eu recollera sobre a educación primaria”, ou os directores da colonia de Mettray, en Tours (a quen visita por terceira vez en 1844) para 315 mozos, saídos das cadeas Francia, ocupados en traballos agrícolas e en obradoiros, subdivididos en familias de 40 colonos.

\section{A antoloxía de textos}

Compuxemos unha antoloxía de textos de valor educativo e históricopedagóxico, mediante fragmentos entresacados fundamentalmente da súa edición francesa (1839) das Viaxes a Bélxica e Holanda, que traducimos ao galego desde

\footnotetext{
${ }^{53}$ Nos seus informes son igualmente valiosas as referencias a textos pedagóxicos e didácticos producidos en tal escenario, do que nos ocupamos noutro momento.
} 
a edición francesa orixinal, aínda que excepcionalmente tamén recollemos algúns textos-fragmentos procedentes tanto da edición en castelán (1844) da anterior obra, como do informe da súa visita a terras de Alemaña (1844). Cómpre salientar que sobre a figura de Ramón de la Sagra, coñecido, valorado, e estudado na súa dimensión de intelectual nos campos sociolóxico, agrícola e botánico, e tamén en parte como teórico social, existen valiosos libros e contribucións, se ben a súa dimensión como estudoso da educación e como analista de políticas e de experiencias escolares e de formación, ten sido ollada de esguello. Deste modo, esta será a primeira vez que unha revista de historia da educación do noso amplo contexto, Sarmiento, se achega e difunde os textos de La Sagra dos que se da conta. A presentación da Antoloxía, que se dispón sen comentarios complementarios por mor da extensión total desta achega, recorre os seguintes epígrafes:

a) Política educativa estatal e organización escolar ${ }^{54}$

b) O valor da educación e da instrución

c) Condicións de vida, traballo e educación da infancia

d) As Sociedades de Fomento da Instrución

e) Organización escolar e metodoloxía didáctica

f) Formación e avaliación do profesorado

g) Educación de xordomudos e $\operatorname{cegos}^{55}$

h) Reportaxes escolares

i) Unha escola particular singular.

Os textos proceden maioritariamente da súa obra Voyage en Hollande et en Belgique...editada en 1839, se ben tamén recollemos dous anacos das súas Notas de viaje...editadas en 1844, dous procedentes da Relación de los viaje, obra editada

\footnotetext{
${ }^{54}$ Neste caso é un apunte entresacado das numerosas páxinas nas que La Sagra argumenta sobre a diferenza dos procesos de escolarización seguidos en Holanda, baixo control estatal e segundo un plano nacional, que aproba por enteiro, e en Bélxica, que aquí se realiza con ampla liberdade de creación de centros e moi ampla presenza de congregacións relixiosas, o que La Sagra desaproba. O seu posible credo masónico, xunto a súa posición sansimoniana poderían intervir nesta toma de posición, sendo de anotar igualmente que un seu irmán chegou a ser grao 33 (Gran Mestre) da masonería en Uruguay. ${ }^{55}$ Tamén neste caso é un breve apunte, entresacado das numerosas páxinas nas que La Sagra atende á organización e aos procedementos didácticos na educación/instrución de nenos e nenas xordomudos e cegos.
} 
en 1844 , e un procedente das súas Lecciones de $1840^{56}$. Así o sinalamos mediante a indicación entre paréntase a fin de cada anaco seleccionado ${ }^{57}$.

\section{Créditos/fontes}

As imaxes 1, 4, 8, 15 e 16 poden localizarse facilmente mesmo en textos como na rede. As demais teñen a súa orixe nas fontes que se indican:

2 e 3: Ramón de la Sagra, Revista de los intereses morales y materiales. Madrid, 1844.

5. Henry Baudin, Les constructions scolaires en Suisse. Genève: Editions d'art, 1907:8.

6. Pierre Furter, Les espaces de la formation. Lausanne, 1983: 103.

7. Claudio Lozano, Antología de textos pedagógicos. Barcelona: PPU, 1982: 269.

9. Louis-Henri Parias (dir.), Histoire general de l'enseignement et de l'éducation en France. París: Nouvelle librairie de France, T. III, 1981: 216.

10. Yves Gaulupeau, La France a l'école. París: Gallimard, 1996: 69.

11. Musée National d'Education, Lire, écrire, compter. MNE: Rouen, 1981.

12. Gaston Mialaret et Jean Vidal, Histoire Mondiale de l'Éducation. París: PUF, 1981, T. III: 257.

13. Louis-Henri Parias (dir.), Histoire general..., op. cit.: 219.

14. Ibid: 110 (Bibliotheque National de París)

17. Yves Gaulupeau, La France a l'école, op. cit.: 74.

\footnotetext{
${ }^{56}$ Vid. Referencias completas: Voyage en Hollande et en Belgique sous le rapport de l'instruction primaire, des etablissements de bienfaisance et des prisons, par....(París: A. Bertrand Ed., 1839, 2 Tt., 300+364 pp). Notas de viaje escritas durante una corta excursión a Francia, Bélgica y Alemania en el otoño de 1843, (Madrid: Imp. de la Guía del Comercio, 1844). Relación de los viajes hechos en Europa bajo el punto de vista de la instrucción y beneficencia pública, la represión, el castigo y la reforma de los delincuentes, los progresos agrícolas e industriales y su influencia en la moralidad (Madrid: Imprenta de Hidalgo, 2 Tt, 175+182 pp). Lecciones de Economía Social, (Madrid: Imp. de Ferrer y Cía., 1840).

${ }^{57}$ No caso dos anacos procedentes da obra de Voyage de 1839 non referimos o Título, pois sería repetitivo, sinalando en todo caso a procedencia do Tomo I, ou do II, e a páxina ou páxinas de orixe. Empregamos os puntos suspensivos cando evitamos traducir un pequeno texto dentro do fragmento seleccionado e, asi mesmo, empregamos os puntos suspensivos entre paréntese (...) cando evitamos traducir un anaco de máis amplitude e formando parte do anaco xeral seleccionado.
} 


\section{Política educativa estatal e organización escolar}

“O progreso dun pobo ten dous puntos de partida: un deles está nas escolas, porque elas conteñen á xeración futura; o outro, pertence ao goberno, porque ten a misión de impulsar todos os movementos que se concilian coa liberdade, coas leis e coa moralidade pública. Cando as escolas están situadas baixo a supervisión e a dirección activa do Estado, hai un desenvolvemento harmónico e equilibrado cara ao progreso, porque a educación popular gradualmente mellorada prepara para as altas funcións do goberno aos homes máis hábiles e honestos; e estes, sentindo máis vivamente o prezo das luces e da moralidade, fan sentir a súa influencia, como un xusto retorno, en canto ao perfeccionamento de todas as institucións públicas" (1839, II, 38)

"Cando as provincias meridionais se uniron baixo a mesma autoridade suprema, o goberno, consciente da deplorable situación do ensino primario entre elas, ocupouse de introducir o mesmo sistema que prosperaba nas provincias do norte. Estaba no seu dereito de reservarse a dirección, porque só ao goberno lle pertence este exercicio, conforme ás leis orgánicas emanadas do Parlamento.O exercicio desta facultade non é un monopolio, senón unha atribución que, antes de pertencerlle a calquera, está mellor situada nas mans do goberno supremo. A educación dun pobo é un asunto demasiado grave como para que poida ser deixado á mercé das opinións inconstantes dos partidos, e como para que se faga depender en canto ao seu progreso dos caprichos, da ignorancia ou do celo esquivo de tal asociación civil ou relixiosa. A súa organización debe ser estable e debe estar sometida a un control activo e incesante; a súa finalidade debe ser fixa e invariable, independente das opinións políticas, fundada sobre os principios eternos e inmutables da relixión e da moral.(...) Con respecto ao protestantismo, a lei holandesa exclúe das escolas toda caste de dogmatismo para que só se poidan escoitar nos seus muros a voz da moral e da relixión, que todas as orellas poidan oír e recibir nos seus corazóns. A propaganda protestante non se podería ter feito máis que a través dos ministros desta seita, que tiñan as portas das escolas cerradas, como no caso dos sacerdotes católicos; e se falamos do espírito que domina entre as dúas clerecías, non é precisamente ao sector católico a quen debe atribuírse a a maior parte da tolerancia.

A exclusión das congregacións relixiosas ensinantes, que non quixeron someterse á formalidade dos exames, lonxe de servir de motivo de acusación contra os principios do goberno holandés, presenta, polo contrario, ao noso parecer, o máis xusto motivo de eloxios pola súa sabedoría e previsión; así que, polo contrario, nós non atopamos ningunha escusa diante dos que se opoñen ás ordes da autoridade" (1839, II, 19-22).

\section{O valor da educación e da instrución}

“A instrución soia, sen estar unida á educación moral e relixiosa, non ofrece contra a inmoralidade o remedio que quixo supoñérselle; a instrución superior, non 
estando unida a un grao correspondente de educación elevada moral e relixiosa, non procura aos individuos os bens intelectuais que tende a promover, e chega a ser nociva ás clases inferiores, que só toman dela medios de prexudicar, ao tempo que a mesma excitación mental producida por tales estudos, tíraas da súa esfera social e perturba a orde físico e moral dos pobos. A instrución primaria é necesaria a todas as clases para a súa existencia e o seu adianto, pero a educación é a única capaz de mellorar a súa moralidade e de dirixilas polo carreiro da virtude. A instrución superior cómprelle ás sociedades, pero debe ser privativa dos individuos que poden ser útiles con ela, e só no número correspondente ás necesidades das nacións". (Lecciones de economía social, 1842, 244)

\section{As Sociedades de Fomento da Instrución}

"A Sociedade de Fomento da Instrución de Liège (Bélxica) ten por obxecto a mellora do medios de ensino, ofrecendo a baixo prezo os mellores libros elementais, e contribuíndo a introducir os mellores métodos. Ten unha sesión pública unha vez ao ano, no mes de setembro, e o seu Consello de administración, ou Xunta Directiva, composto de 20 membros reúnese, cando menos, unha vez por mes. Subdivídese en subcomisións e os seus informes e proposicións serven de base para os traballos da asemblea: por exemplo, a primeira sección busca e indica os libros que ofrecen coñecementos útiles expostos con sinxeleza e destinados a estender o gusto polo traballo e o amor ás virtudes, así como aqueles outros cuxa tradución puidera contribuír aos mesmos resultados; a segunda sección prepara os medios para facer a distribución máis vantaxosa dos libros e para isto reúne as informacións precisas e ocúpase de clasificar as obras segundo os graos de instrución e as necesidades das localidades.

A rapidez da venda dos libros que publica esta sociedade pode servir para darse ben de conta do que ela produce. En 1830, cando só tiña tres anos de vida, xa tiña colocado case 80.000 libros, e desde a súa orixe até 1836 imprimiu ou adquiriu 316.416 volumes. As publicacións foron constantemente en aumento... até os 33.850 do penúltimo ano. Só neste último ano a sociedade imprimiu 67.000 exemplares, e ningunha edición tivo unha tirada de menos de 3.000 exemplares: o almacén contén máis de 120.000 volumes de 46 obras diferentes. Entre as publicacións máis interesantes desta Sociedade citarei os cadernos de debuxo lineal, de carpintaría e de arquitectura, os mapas xeográficos e os globos, todo a prezos moi moderados.

Os traballos desta sociedade estendéronse a outras ramas importantes que completan o círculo da súa influenza e que indicarei rapidamente. En 1836 estableceu, a través de concerto coa rexencia de Liexe, unha escola normal primaria con ensino gratuíto e os alumnos non teñen que ocuparse doutra cousa que a súa subsistencia, e mesmo obtiveron de inmediato do consello municipal unha axuda de 6.000 francos en favor dos alumnos que viven lonxe da escola. Os 
mestres auxiliares e os seus axudantes, así como as mestras auxiliares das escolas da contorna deben asistir aos seus cursos. Estes cursos divídense en dúas partes; no primeiro curso de oito meses de duración permanente, de outubro a maio, as leccións teñen lugar pola tarde en cinco días cada semana; tres para os mozos e dúas para as alumnas. No $2^{\circ}$ curso, con sesións temporais, aínda que con cursos permanentes durante os meses de vacacións, veñen á Escola os mestres rurais da provincia que teñen necesidade de perfeccionarse, e asisten todos os días durante dúas horas pola mañá e dúas pola tarde...A mesma sociedade aínda se ocupa doutras iniciativas escolares" (1839, II, 54-56).

\section{Condicións de vida, traballo e educación da infancia}

\section{A ineficacia legal:}

"No estado presente da industria, nos países máis adiantados, a escola e o taller parecen incompatibles, pois o reducido dos xornais obriga aos pais a tirar partido dos seus fillos desde a máis tenra idade, para axudar a manterse. Emporiso as leis humanitarias que determinan a idade e o tempo para o traballo dos nenos nas manufacturas, os regulamentos severos para a asistencia ás escolas, e outra porción de prescricións resultan máis ou menos ineficaces, porque van contra o interese das familias e dos fabricantes, e son contraditorias con certos principios vitais, aínda que viciosos, da industria moderna. Baixo o punto de vista da instrución industrial, as familias xornaleiras tampouco llela poden procurar moi cumprida aos seus fillos, ben porque é nula ou incompleta a escolar, ou porque a súa posición social impídelles colocalos en talleres, acreditándose baixo a dirección de mestres hábiles e honrados.

Por estas mesmas causas, resulta defectuosa a aprendizaxe dos mozos, e tan incerta a súa colocación futura como gravosa a súa subsistencia baixo o teito doméstico. Resulta de todas estas tristes condicións a case imposibilidade en que se atopan as familias proletarias de proveer ao ensino, ao alimento, ao vestido e á colocación dos seus fillos" (Notas de viaje..., 1844, 148).

\section{Aleitamento, pauperismo, traballo dos nenos e escolas infantís:}

"O pauperismo imposibilítalle de todo punto ás nais xornaleiras ocuparse na educación e no coidado dos fillos. Aleitar aos fillos é para elas un asunto penoso, xa que encadea un ano ou máis da súa existencia, e non será estraño que dentro dalgún tempo a administración pública ou a caridade individual discorran medios para que as nais poidan tamén destinar ao traballo este primeiro período reclamado polos nenos menores de dous anos. As escolas de párvulos atenden xa ás necesidades do segundo período, entre os dous e os seis, aínda que o número vai sendo tan crecido que será tamén preciso ocuparse en utilizar as forzas destas criaturas para que sequera gañen unha parte do pan que os seus pais non poden 
darlles. Algo disto hai xa nas escolas destinadas en Holanda e en Alemaña para os nenos das clases pobres. Cando comuniquei estas noticias aos meus amigos, acabado de chegar da miña viaxe de 1838, dicíame (en París) madame Mojon, tan instruída como previsora contra das tendencias do momento: 'coidado que tal ocupación dos nenos, que vostede acaba de ver adoptada, máis que como medio económico e axente moralizador, non dexenere en axente de tiranía, por chegar a chamar a atención dos calculadores egoistas'. É, en efecto, as previsións da miña amiga xa se cumpren: veño de Prusia onde se organiza o traballo de fiado á man nas escolas infantís" (Notas de viaje..., 1844, 155).

\section{Organización escolar e metodoloxía didáctica}

\section{A contraposición da metodoloxía das salas de asilo: Francia/ Holanda}

“O ensino (en Holanda) é moi positivo, excesivamente serio; os xogos e recreacións son moi raros; e nisto é una mágoa que non se siga o exemplo de Francia. Nas salas de asilo de París pódese dicir que todo se aprende xogando e cantando. Os nenos, dirixidos por un impulso común -pois aquí non hai clases separadas- todos están en movemento...; non teñen a súa atención servilmente fixada sobre longos cálculos. Todo é ledicia, dozura e variedade; o esencial é o xogo; o accesorio, a súa instrución. Porén, o xogo pasa e a instrución permanece con útiles hábitos de atención, de obediencia e de submisión, hábitos que o neno adquire mesmo sen darse de conta. En Holanda, pola contra, os exercicios de xogo forman algo aparte e non teñen nada en común co traballo. Durante as horas de clase é o traballo o que domina, o que lle da ás escolas o seu carácter grave e serio. Os nenos cantan, é certo, e moi ben; máis, só é canto; non xogan, non marchan cantando; nada hai de común entre o canto e o xogo, como tampouco entre o xogo e o estudo, tres cousas que deberían unirse, combinarse e fundirse como unha soia... Valoro, aínda así, que os medios empregados en Holanda, por máis que completamente diferentes dos usados en Francia, producen, con todo, admirables resultados: ten que ver seguramente co carácter particular dos nenos holandeses, pois despois de visitar as escolas de Holanda estou convencido de que os traballos graves e serios case non cansan aos nenos deste país, mentres que enxendrarían a xenreira e o aburrimento dos nenos das escolas de Francia e de España. Esta diversidade de carácter atópase igualmente por enteiro no xenio dos Mestres holandeses dos dous sexos, que dispoñen dun profundo coñecemento da arte de ensinar, dunha constancia a toda proba, dunha dozura e dunha especie de familiaridade naïf nas relación cos nenos, que cativa o espírito e a afección da xuventude" (1839, I, 77-79).

"Por todas partes hai numerosas escolas ben dirixidas e cheas dunha rapazada tan fermosa como laboriosa (...) Pódese asegurar que as escolas rurais son, proporcionalmente, máis frecuentadas cás das cidades" $(1839, \mathrm{I}, 81)$. 


\section{Contra a organización das escolas lancasterianas ou mutuas:}

"Se as autoridades (de Bruxelas) estivesen convencidas desta saúdable máxima, que é o principio de asociación da educación e a instrución, non empregarían os seus fondos en crear escolas lancasterianas, que teñen un sistema maquinal, mecánico, absurdo e directamente oposto á finalidade da educación popular.

En Bruxelas visitei a grande escola desta clase restablecida recentemente nun magnífico local no que chegan a reunirse 300 nenos e 150 nenas; o seu director modificou varias das normas do sistema lancasteriano, pero no fondo este mantense: a repetición mecánica do ensino por parte dos alumnos, a transformación do principio do desenvolvemento progresivo da intelixencia en simples hábitos de memoria, a supresión de todo elemento racional de actividade e de vida no espírito dos nenos e, o que é máis triste, de todo medio de reacción en canto aos sentimentos morais por parte do corazón, única fonte onde reside o futuro secreto e descoñecido cara á que o método adoptado debe dar unha sabia dirección... O mestre, usando probablemente facultades discrecionais que lle concederon, fai aprender aos alumnos algunhas nocións de física e de historia natural que son estrañas ao círculo do ensino primario, mesmo poida que explicadas dun xeito pouco conveniente para a infancia. Os alumnos aprenden así o debuxo lineal, seguindo os fermosos modelos publicados pola Sociedade de impulso. As nenas reciben ensino sobre os traballos do seu sexo nunha sala grande separada da dos nenos, e baixo a dirección dunha mestra" (1839, II, p.50).

\section{Formación do profesorado e exames profesionais}

"Se o exercicio do profesorado pode ser considerado como un acto de beneficencia e de piedade, sen embargo este carácter non autoriza de ningún modo a deixalo entre as mans de calquera que se sinta animado do nobre sentimento de facer o ben. Se o ensino da infancia é incontestablemente unha boa acción, o seu exercicio require, ademais dunha alma benfeitora no mestre, un fondo de instrución conveniente que é absolutamente independente da vontade do corazón. Para ensinar é necesario saber, e isto non quere dicir só posuír un alma caritativa e cristiá. As congregacións relixiosas que, sen ser chamadas, pretendían dirixir o ensino da infancia, puideron actuar desde o principio en virtude dun sentimento de piedade que estou lonxe de combater; mais, desde o momento no que unha lei estatal establecía a necesidade previa dun exame para o exercicio do profesorado, os membros destas congregacións debían someterse ás formalidades esixidas" (1839, II, 21).

“As provincias do Norte de Holanda organizaron en Groninga en 1818 unha Escola Normal por mor das atencións da Sociedade de Ben Público: para ser admitidos os alumnos deben ter, polo menos, catorce anos;... por escrito comprométense a obedecer e a consagrarse ao ensino en centros públicos e nunca en casas privadas. Comprométense a ensinar gratuitamente a escritura, os principios do debuxo, o canto, a aritmética, a historia xeral, a historia sagrada e a 
do país, a xeografía, os elementos de física, a historia natural, a relixión, a moral, os principios fundamentais da lingua holandesa e da lingua francesa, e tamén a teoría e a práctica do ensino. Hai tamén aquí una escola anexa, da que forma parte esencial; recibe 60 nenos que pagan cada mes unha retribución fixa. Os alumnos máis novos da Escola Normal continúan durante algún tempo a realizar os exercicios da terceira clase da escola primaria; logo asisten como auxiliares ás escolas gratuítas da cidade e exercítanse así na práctica do ensino. Traballan todos os días de 9 a 12 e e 2 a 4 da tarde, agás o sábado. Este día, así como as tardes de todos os outros, está reservado para a súa instrución particular: é entón cando se aplican ás diferentes ramas e estudos das que falamos” (1839, I, p. 86-87).

\section{Educación de xordomudos e cegos}

"En toda Bélxica hai oito establecementos consagrados ao ensino de xordomudos e cegos, sendo o máis antigo o de rapazas de Gante, fundado en 1808; o de Liexe estableceuse en 1820; o de rapaces de Gante en 1825; o de Bruxelas, para as nenas, en 1834; o de varóns en 1835; e tamén o de Bruges do mesmo ano 1835. En 1834 estableceuse outra institución confiada aos coidados da irmá Constanza, que eu coñecera en París en 1837, e que despois da súa morte foi transferido a Yprès, nun mellor local e nunha situación máis conveniente. Por fin, neste presente ano de 1838 ven de abrirse en Mons, baixo a dirección do señor E. George, un instituto particular da mesma clase, en favor do que se agarda a protección do goberno e do consello provincial de Hainaut, como se fai nos demais establecementos nas súas provincias respectivas. Pois, en efecto, todos os centros belgas desta clase comezaron por ser sostidos polos celo e a caridade de persoas benfeitoras; catro de entre eles foron debidos en exclusiva ao cóengo Triest, e obtiveron de seguida a protección e as axudas do estado, das provincias e dos concellos respectivos, e deste modo puideron estender os seus beneficios sobre un maior número de infelices, e ofrecer ao mesmo tempo en todos os centros as vantaxes das que desexan gozar todos os membros das clases ricas. Os primeiros establecementos sinalados limitábanse ao ensino de xordomudos, até que o señor Sauveur organizou en Bélxica o de cegos, unha vez que o ministro do Interior tiña enviado a París ao señor abade Carton, en 1837, para que completase os seus estudos nesta póla, e despois a Inglaterra, a Escocia e a Irlanda" (1839, II, 192-3).

"Eu visitei cinco destes oito establecementos. O exame deles e as miñas relacións co honorable director, abbé Cartón, permitíronme coñecer con exactitude o estado deste ensino en Bélxica".

\section{Reportaxes escolares}

\section{1.- Leeuwarde}

"Detívenme no exame das tres escolas principais da cidade, dúas delas enteiramente gratuítas e outra intermedia, con algún pago semanal por parte de cada 
alumno. Na primeira, con horario que vai das 9 da mañá até as 4 da tarde, sen contar o tempo do xantar, recíbense 250 alumnos dos dous sexos durante a mañá, e 150 pola tarde. A segunda escola gratuíta, que abre ás 10 da mañá, recibe o mesmo número de alumnos, tanto pola mañá como pola tarde; a terceira das escolas, de pago, ocupa un magnífico local, construído para esta misión, hai pouco tempo; conta con 300 alumnos pola mañá e 220 pola tarde. $O$ total de alumnos, pois, é de 1.320 alumnos.

O sistema e o plan de ensino son comúns ás tres, de modo que a terceira escola só difire das anteriores pola fermosura do local e polo coidado con que veñen vestidos os nenos á escola. Todos os alumnos das tres escolas teñen asento en bancos, diante dos que se levantan longas mesas; os nenos e as nenas están xuntos e só están divididos en catro categorías. Hai en cada un dos tres centros un director e un número suficiente de mestres auxiliares. Os alumnos máis intelixentes, os que amosan disposicións para o ensino, serven de repetidores para os nenos da clase dos principiantes.

Tamén as tres escolas teñen un mobiliario similar: alén dos libros e instrumentos de escritura, que se lles dá gratuitamente aos alumnos, cada unha posúe un círculo xiratorio, de arredor de tres pés e medio de diámetro: sérvense del para ensinar a formación dos sons por medio das sílabas; diversas cartas xeográficas impresas; a de Frisia, debuxada a grande escala e sobre unha tea, presentando á vez os ríos, as divisións municipais, e a posición das cidades, aínda que sen indicar ningún nome; diversos cadros sobre os que se poden ler as primeiras nocións de música e canto; unha colección de pesos e medidas decimais, cuxo sistema debe ser ensinado en todas as escolas primarias de Holanda, por virtude dun decreto de 1828; cantidade de caixas cheas de froitos secos, de sementes e outros obxectos, para as leccións de cousas, e numerosos gravados para o estudo do debuxo.

O círculo do que acabo de falar é moi útil para ensinar a formación das palabras; leva inscritas na súa circunferencia un grande número de sílabas simples e dobres: cando se lle fai xirar sobre o seu centro, preséntaselle aos nenos a silaba pedida, trazada horizontalmente, na disposición máis favorable para a lectura. Á esquerda deste círculo e tanxente coa circunferencia pode moverse á vontade un taboleiro vertical no que tamén aparecen escritas diferentes sílabas que, presentadas a continuación de aquelas que están no círculo xiratorio, forman un número grande de sons variados e distintos, en relación cos que o profesor explica sucesivamente a pronunciación, o senso e o valor. Os instrumentos están montados sobre un cabalete.

As leccións de escritura, de quitadas as primeiras nocións, danse desde o comezo sobre papel non pautado. Cada alumno ten o seu propio caderno, sobre o que escribe a súa páxina, no intervalo dunha clase á seguinte, e no comezo do que o mestre escribe a data do día. Desta maneira, é suficiente pasar as follas deste caderno e examinar as súas datas para ter unha idea exacta dos progresos máis ou menos rápidos de cada alumno. 
Todos os alumnos baixo a dirección do mestre ou dos auxiliares exercítanse en cantar unha música simple e delicada, composta expresamente para eles e publicada nos numerosos Manuais escolares que eu teño (sic). A harmonía de todas estas voces infantís, o aspecto desta rapazada pobremente vestida, mais moi limpa, todo aquí presenta un conxunto do máis alto interese, aínda máis agradable á vista por mor da admirable cor como de rosa da raza holandesa e o aspecto brillante dos seus cabelos roibos.

Todas as partes do ensino primario, ordenadas pola lei, son ensinadas con exactitude nestas escolas; con todo, o que máis me asombrou, e que eu vin entón por primeira vez, foron as clases de debuxo: nelas, sen mestre especial, sen que o director ou os auxiliares se sintan obrigados a saber nada, os nenos debuxan e perfecciónanse eles mesmos nesta arte. O método empregado consiste en presentarlle sucesivamente aos alumnos unha serie de gravados, ao comezo simples, regulares, xeométricos, e logo irregulares e complicados: froitas, flores, animais, edificios, paisaxes, etc. Eles exercítanse, entón; adquiren pouco a pouco unha certa habilidade, corrixen os seus erros e terminan por imitar, con asombrosa perfección, as estampas máis complicadas da colección. Estes resultados causáronme unha viva sorpresa, non tanto polo progreso que son capaces de presentar, canto pola xeneralidade deste progreso, similar en todos os rapaces. O ensino do debuxo por medio de xogos érame descoñecido; eu vira en París, repetir os exercicios por parte dos nenos de madame Mojon, dama italiana de finura de espírito, que a tantas calidades singulares une a máis fermosa de todas, a de ser unha boa nai, dedicada exclusivamente á educación dos seus dous fillos. A primeira infancia, dicíame ela, non ten aínda hábitos, e por isto está nas mellores condicións para vencer todos os obstáculos, precisamente porque todo lle é igualmente estraño. Nós, en troques atopamos insoportables os traballos de aprendizaxe. Por exemplo, resúltanos complicado debuxar unha cadeira en perspectiva, porque nós xa temos unha imaxe fixa da cadeira; tal como é non somos capaces de facelo, senón como nós temos por costume ver as cousas, o que nos impide debuxar coa exactitude e a facilidade que o pode facer un neno.

Sucede o mesmo coa ortografía; madame Mojon aplica uns principios análogos e as súas observacións parécenme dobremente xustas despois de ver os progresos do alumnos en Zwolle. Un neno - dí ela- que comeza a aprender unha lingua, oíndoa ler e traducir ao mesmo tempo, escribiraa ao ditado e reproducira con exactitude sobre o papel a expresión das palabras, coas que recibiu por primeira vez as primeiras nocións deste idioma. Non fará notar as diferenzas ortográficas que existan entre esta lingua e a súa lingua materna; non dubidará; escribirá con fe naïf o que acaba de ler e non irá máis lonxe. Despois dos nenos, quen manifestan maior aptitude para aprender unha lingua viva son a xente do pobo e as mulleres: aprenden confiadamente e non perden o tempo en analizar e en comparar as construcións da lingua estranxeira coas da súa propia lingua; traballo que eu estou lonxe de desaprobar, cando iso se fai nun tempo oportuno, mais non en prexuízo dos progresos aos que se aspira no caso da práctica dun idioma novo. 
É doado de comprender que todas estas ideas se me viñan á mente cando eu vin as escolas de Leeuwarde. A orde e a disciplina destas escolas son observadas en todas as cousas e con puntualidade. $\mathrm{O}$ director, axudado por algúns dos alumnos máis adiantados, mantén ao día os diferentes rexistros:

- Un rexistro de matrícula, onde se inscriben os nomes dos alumnos, co seu lugar de nacemento, a súa relixión, idade, data de admisión, etc., etc.

- Un rexistro, onde se inscribe cada tres meses o resume das notas semanais, boas ou malas, que mereceron os alumnos; na fin do ano, na época de exames, examínase este rexistro para saber a que alumnos hai que concederlles recompensas e premios.

- Un terceiro rexistro, chamado rexistro de vacinas, está destinado a consignar a idade de cada neno no momento de ser vacinado, os nomes dos seus país, do médico, etc.

Todos os rexistros, feitos con coidado, limpeza e puntualidade irreprochables, están a disposición do inspector e dos membros da comisión das escolas, que os consultan en calquera momento. Volverei máis tarde sobre ese sistema vicioso de rexistros de recompensas dos alumnos nas escolas, e os seus inconvenientes foron observados incluso en Holanda.

Do mesmo modo que a educación profana, a instrución relixiosa nas escolas primarias está sometida aos principios do método xeral. $\mathrm{O}$ art. 22 do regulamento anexo á Lei de 1806 sinala que a súa finalidade é o exercicio de todas as virtudes sociais e cristiás; ao mesmo tempo, o art. 23, prohibe absolutamente nas escolas o ensino do dogma. Deste xeito, o preceptor só ten a responsabilidade da instrución moral e relixiosa, quedando para os ministros dos diferentes cultos, ao que pertenzan os nenos, explicarlles os dogmas nas súas igrexas respectivas. Pola súa parte, os preceptores apréndenlles aos seus alumnos os feitos da historia sagrada, centrándose con atención nas cuestións e nos sucedidos que dean pé ás observacións e ás reflexións morais apropiadas para os cativos; tiran partido dos incidentes que se presentan nas clases, dos exemplos tirados das lecturas, das accións de cada un, en fin, para inculcarlles os principios salvíficos do cristianismo, o amor a Deus e aos demais, as virtudes sociais e todo o que pode contribuír á educación do corazón. Nestas circunstancias tense o maior coidado en non excitar a imaxinación dos alumnos mediante exemplos que, sendo convenientes para os nenos acomodados, non o son para os nenos pobres; evítase espertar inutilmente os desexos destes, e mesmo elevar os seus espíritos fóra do círculo onde os ten cativos a súa pobreza; evítase facer nacer neles sentimentos de vaidade e de ambición, que son fonte de desgusto e de penas para os simples artesáns! En atención a esta regra, os mestres de escola de Leeuwarde son pouco pródigos en amosar a historia profana: ensínana con restrición, e limítanse, máis a miudo, a tomar da historia nacional aquilo que pode ser de máis utilidade para o pobo, apartando escrupulosamente o que puidese facer crecer as súas necesidades. 
Debo recoñecer que a capacidade dos mestres, o saber e o celo dos inspectores, a posición social e científica dos membros das comisións, son garantías que aseguran a perfección do sistema adoptado, sistema que remite a cada profesor o coidado de aprenderlles aos alumnos a moral e a relixión considerada nas súas xeneralidades, e sen ningunha mestura cos principios do dogma. Un día que eu trataba este asunto co inspector Van der Plaats, díxome: 'eu, como inspector de escolas, non son nin protestante, nin luterano, nin católico; eu son cristiá; os principios do cristianismo son os que se lle deben inculcar aos nenos" (1839, I, 97-106).

\section{2.- Zwolle}

"O principio fundamental destas escolas de Zwolle, co fin de conducir gradualmente ao fillo do pobre desde a sala de asilo até o taller, pasa por asociar ao mesmo tempo a ensinanza primaria con outro sistema ben calculado de socorros aos pobres..., para dar educación e traballo aos fillos" (Relación..., II, 1844, 21)

"O local é unha sala espazosa, provista de bancos e de mesas, sobre as que os nenos depositan a lousa, como en todas as escolas. As explicacións escríbense sobre un encerado, coa axuda de figuras, de gravados e de outros obxectos. Hai una mestra directora, e catro ou seis rapazas, mestras auxiliares encargadas de repetir as leccións. O seu número é grande, para prover, segundo se necesite, de mestras instruídas a outras escolas (...)

Os nenos estarán na sala de asilo até a idade requirida para pasar ás escolas primarias anexas a este centro, ou á escola gratuíta que sostén a cidade. O regulamento expón os medios para desenvolver a intelixencia, ao mesmo tempo que as facultades físicas, coa axuda de exercicios apropiados ou, en fin, a educación moral, baseada sobre o amor a Deus e ao próximo.

Os que comezan, colocados arredor dunha mesa redonda e confiados ao coidado dunha mestra auxiliar, exercítanse primeiro en distinguir as formas, as proporciones e as cores dos obxectos; aprenden a contalos e a dispoñelos de diversos modos; mídenos e realizan todas as combinacións adecuadas para facer traballar á vez os sentidos e a intelixencia. Cando chegan á segunda clase, continúan sobre o encerado os seus exercicios de combinacións e de formas; explícanselles as relacións e as diferenzas; fáiselles marcar sobre as súas lousas todos os exemplos dos que, á súa volta, deben das novas explicacións. É así como aprenden a representar os signos e a dicir como ocorre para que dúas liñas non se toquen; como se poden encontrar tres liñas, como catro, como cinco... (Todos estes métodos están sacados dos sistemas de ensinanza intelectual dos señores Prinsen e Van Dapperen, expostos de modo claro e sucinto por M. Van Nerum en Essai sur l'instruction primaire, Gand, 1938).

Ao mesmo tempo que estudan as formas, aprenden sen dolor, a numeración simple, por medio de puntos negros dispostos simetricamente. Deseguido mostránselles cifras gravadas sobre dados de madeira; ensínaselles a formar 
números, a multiplicalos entre eles, e así se desenvolve o sistema completo da numeración.

Continúan as leccións de cousas mediante láminas ou a través dos obxectos mesmos: a estes efectos a escola posúe unha colección de láminas, un gran número de caixas chenas de sementes, de metais e de outras materias primas, cuxa explicación forma el obxecto de exercicios moi entretidos. Todo isto fai nacer explicacións detalladas.

Finalmente, ensínaselles aos nenos a formar as letras do alfabeto, a pronunciar as vogais e as sílabas que eles compoñen, xuntándoas coas consonantes, a dicir palabras enteiras e a compoñer cos dados de madeira, nos que están inscritas as letras: son conducidos, así, a coordinar frases enteiras e a compoñer as leis da ortografía. En canto ao cálculo, os nenos aprenden no só o sistema completo da numeración, de modo a poder descifrar normalmente toda clase de números escritos, senón tamén a sumar, a restar e a multiplicar; aínda mesmo reciben unha tintura da división.

Os exercicios de lectura e de aritmética, sorprendéronme realmente. Só citarei un dos más simples, tratándose de analizar se un texto estaba ben redactado no encerado: un grande número de nenos levantaban a man para dicir o que consideraban erros, corrixindo deste xeito 24 faltas de gramática e ortografía nunha historieta de 40 palabras en holandés. E así outros escritos, para outras probas.

Ensínaselles pronto a cantar e a perfeccionar a súa pronunciación: cada un dos diversos exercicios é ocasión para desenvolver algún pensamento moral, que é sempre presentado baixo a forma máis interesante e conveniente á idade e ás necesidades da infancia. A infatigable actividade da directora, o seu saber e o seu carácter, á vez enérxico e cheo de dozura, operan nesta sala de asilo auténticos prodixios.

Tal é o sistema de ensinanza, dicíame o señor Luttenberg, que os nenos recorren toda a escala sen problemas, chegando por eles mesmos a estes resultados notables, que a min tanto me chamaron a atención. Aseguroume que estes coñecementos preparatorios...eran de gran avance para estes nenos, que pola súa indixencia non podían asistir moito tempo ás leccións das escolas primarias. O paso a estas é insensible; aprenden nun ou en dous anos todo o que eles teñen necesidade de saber, e desta forma quédalles bastante tempo para exercitarse nalgúns traballos útiles e produtivos; así, os fillos dos artesáns terminan a súa educación primaria antes dos doce anos, e entran de inmediato na preparación profesional: entón asisten pola tarde ás repeticións das escolas e adquiren outros coñecementos de orde máis elevada" (1839, I, 66-72).

"En Zwolle os alumnos de máis idade van ás escolas de fiar lá e de tecer polas mañás, e pola tarde, de cinco a oito, van ás aulas de escola primaria. Tómase nota 
cada día do seu traballo e o sábado págaselles con diñeiro o traballo da semana... Fano así para habitualos ao traballo e procúranlles unha ocupación.

Estas escolas primarias e de traballo son catro; dúas propiamente consagradas ao ensino primario ás que asisten nenos dun e outro sexo, e dúas consagradas ao traballo, unha para rapaces que fían e tecen e outra para as rapazas. A cifra total de alumnos chega a 590. Cando os nenos de sexo masculino terminan a súa instrución son colocados como aprendices nos talleres baixo a tutela da Comisión. As rapazas máis adiantadas pasan á escola de costura, ou traballan para as súas familias. E para que non esquezan nada do que aprenderon estableceuse unha escola gratuíta con clases de sete a nove da tarde e conta con 260 alumnos, que polo día traballan en distintas ocupacións. Así, hai un sistema completo de educación primaria, industrial e moral, do que se aproveita a multitude de nenos, desde a idade de 10 anos até o momento en que aprenden un oficio; ademais, reciben o prezo do seu traballo, retribución que é de grande axuda para as familias pobres" (1839, I, 82-84).

\section{3.- Rotterdam}

"A sala de asilo de Rotterdam conta con 200 alumnos. Ocupa un moi fermoso local, disposto para este uso, cun fermoso patio de entrada e outro interior. Está provista de todos os utensilios necesarios para a educación dos nenos; admiro a limpeza, as dúas salas de exercicio, unha delas perfectamente aireada, e outra, máis pequena, consagrada aos nenos que comezan, que son uns 60. Os nenos e as nenas están divididos en tres categorías, sen que haxa, sen embargo, ningunha separación. O sistema de ensino é parecido ao de Zwolle, con menos material” $(1839, \mathrm{I}, 75)$.

\section{4.- Groninga}

"Visitei en Groninga outra sala de asilo, non gratuíta, establecida pola Sociedade do Ben Público...O sistema de ensino é absolutamente parecido ao de Swolle. A sala está dirixida por una dama auxiliada polo seu marido e unha mestra auxiliar. O marido encárgase de animar aos nenos: fainos cantar e acompáñaos ao piano. Eu fago notar por primeira vez que os nenos se servían dunha especie de lapis de pizarra (ou lousa) para escribir sobre as súas lousas, envolto nunha cuberta de madeira, e parecido aos nosos lapiseiros ordinarios. Este procedemento ten a vantaxe de exercitar desde o comezo a man dos nenos en escribir, dispondo os dedos como se se servisen dunha pluma (ou caneta)(...).

Para ensinarlles aos nenos o coñecemento das cifras, das letras e das combinacións, a escola emprega, ademais dos dados de madeira, unha especie de pequenos pupitres onde estes dados se atopan dispostos sobre dúas liñas, cun espazo libre que os nenos aproveitan para compoñer as cantidades ou as palabras que a mestra escribe no encerado. Estes pupitres, que eu vin que se usaban en case todas as escolas primarias de Groninga e Frisia, son moi cómodos e pouco custosos" (1839, I, 73-74). 


\section{5.- Anvers}

"Hai tres escolas municipais, gratuítas, divididas cada unha en oito clases; a lingua flamenga, que é a máis usual e a máis necesaria en Anvers, é ensinada de modo preferente, pero nas tres clases máis adiantadas ocúpanse sobre todo da lingua francesa. Van ás escolas 1.000 nenos e 300 nenas. Eu visitei unha destas escolas en compañía do burgomestre señor Gerard de Grelle; está establecida nun fermoso local veciño do taller de traballo dos pobres. A sala ten 30 metros de longo, 10 de ancho e 8 de altura; está perfectamente aireada e iluminada; reúne 300 nenos da clase pobre, ben atendidos, calzados con zapatos, e que alí están con comodidade. O método seguido neste establecemento e nas outras dúas escolas gratuítas é o de Lancaster, de modo que as autoridades municipais deberán introducir unha reforma esencial, sen a que os seus esforzos non terán verdadeiro éxito. A conservación e a consideración que se fai do sistema lancasteriano en Anvers ven, sen dúbida, de que foi o que se impuxo en 1818 ao establecemento da primeira escola de pobres, como modo de comparación. A escola permaneceu, e o estudo comparado dos métodos aínda non se fixo en Bélxica; mais, téndose resolto a cuestión nas outras nacións contra o ensino lancasteriano, Anvers non debería tardar tanto tempo en proscribilo para elevar o seu sistema escolar á altura que lle convén" (1839, II, 69).

\section{6.- Verviers}

"Visitei con atención varios destes establecementos en Bruxelas, Liexe e Verviers. Os mellores e máis ben organizados están nesta pequena cidade manufactureira, sostidos mediante subscrición particular e unha pequena subvención da cidade, e dirixidos por unha comisión de donas benfeitoras. Son tres escolas de párvulos, e unha máis que vai ser aberta. Dous dos centros conteñen 300 nenos; na maior, que visitei, reúnense ordinariamente 200 nenos, e hai case 250 no rexistro de inscrición.

O local desta escola é o máis fermoso e o máis grande que eu nunca vira, e o edificio foi construído exclusivamente para esta finalidade. Está precedido por un patio grande. $\mathrm{Na}$ entrada hai unha pequena sala, e a continuación outra para lavar aos nenos; hai varias latrinas moi ben establecidas. De seguido, pódese pasar a unha sala inmensa onde xogan os nenos nos días de moita auga e durante o inverno. Todo ao seu redor dispuxéronse dúas liñas de andeis onde se colocan as pequenas provisións de boca que os nenos aportan. Provisións que son colocadas en pequenas cantinas; isto é, dous compartimentos de forma oval, de ferro branqueado, e superpostos, un para a sopa e o outros para as patacas ou a carne. $\mathrm{O}$ centro merca estas pequenas cantinas co seu diñeiro, o mesmo que as culleres e algúns mandilóns, que entrega ao prezo moderado do seu custe, aínda que en lugar de esixir o diñeiro, o centro pide a cambio un número determinado de 'billetes de aplicación e de progreso', a razón dun céntimo ou dous cada un. 
Despois desta grande sala de recreación atópase a sala de exercicios, tamén suficientemente ampla, con gradaría ao fondo, ábacos para a numeración e unha especie de cama de acampada para os nenos adurmiñados; e logo, algúns outros obxectos para o ensino, aínda que este mobiliario é moi reducido.

Esta gran escola, e probablemente tamén as outras de Verviers, carece de arquivador e mostras para as explicacións dos obxectos; tampouco dispoñen de dados numerados nin de letras soltas do alfabeto, nin teñen os corpos xeométricos, nin a colección variada de estampas, nin os ábacos para explicar as fraccións; carecen, en fin, dunha infinidade de cousas que contribúen a facer atractivo o ensino que se lle da aos nenos, ofrecendo ao mesmo tempo tantos recursos ás educadoras, para poder variar e modificar até o infinito os exercicios e evitar a repugnancia da monotonía, (que é) o maior problema de todas as salas de asilo.

Os nenos desta sala de Verviers aprenden a cantar, e eu non sabería como recomendar aínda máis a utilidade desta práctica ás donas da comisión directiva. O canto é o grande medio para provocar sentimentos doces e afectuosos na alma da infancia, e como tal é un poderoso auxiliar da educación. Cando se chega a facer vibrar as cordas do corazón, non digo do neno só, senón tamén dos adultos, nada hai máis doado que facer nacer todas as ideas boas e xenerosas; a alma recíbeas como un alimento compatible coa súa natureza, e a intelixencia iníciase nas máximas da moral relixiosa, gravándoas profundamente e con aquela enerxía que deixa imborrables recordos.

...Alén das imperfeccións que eu atopei, que teñen que ver coa carencia de diversos obxectos necesarios para o ensino e a distracción dos nenos, a escola de párvulos de Verviers está ben dirixida. A institutriz, así como a mestra auxiliar, son persoas afectuosas, que queren aos nenos, impregnadas de docilidade, e ben dispostas para favorecer o progreso. A comisión de donas non deixará, logo, de secundar estas excelentes disposicións, facilitándolles ás mestras os obxectos, pouco custosos, que son necesarios para axudar aos medios naturais" (1839, II, 42-44).

\section{7.- Bruxas}

“O local está dividido en dúas partes: unha para os alumnos da real escola primaria, en número de máis de 500, todos tan apertados nos seus bancos que non poden mover os brazos, e outra na que reuniron aos nenos máis pequeniños, ás veces en número de 200. Moitos deles permanecen todo o día na escola, e vinos xogar no terreo que hai diante do edificio. Moi impropiamente dáselles o nome de escolas gardiennes (salas de asilo, ou gardarías) ás escolas de Bruges porque teñen baixo o seu coidado aos nenos menores de seis anos, porque non ofrecen nin na súa organización nin nos seus resultados nada do que debe constituír este xénero de establecementos: trátase unicamente de escolas primarias gratuítas, onde se admite a nenos menores de seis anos, limitándose a mantelos tranquilos, durante o 
tempo en que os maiores se dedican aos seus deberes, na agarda das horas felices do recreo. Adoptaron tamén en Bruges para o ensino o método de Pestalozzi, modificado por Prinsen, ou sistema intelectual; mais, a escola que visitei deixa aínda moito que desexar comparativamente coas de Holanda” (1839, II, p. 65).

\section{Unha escola particular singular}

"Non quixen deixar Groninga sen visitar a escola particular que dirixe M. Rijkens; o profesor non estaba avisado da miña visita e eu entrei na súa escola sen facerme anunciar. Así que o sorprendín nunha das catro divisións que na escola estableceu. Facía solfexo, en compañía dun violín, diante duns trinta nenos pequenos dun e do outro sexo, entre os que o maior deles tiña sete anos. O seu aire ledo e cheo de franqueza, o calor que poñía neste exercicio, a fisionomía feliz do alumnado, todo me revelou un magnífico profesor, un verdadeiro amigo da infancia. Rogueille insistentemente que continuara a lección e el accedeu: 'Cantade comigo, meus nenos, díxolles, aaaaaaa A aaaaaa'; e os nenos repetían con el esta vogal, en toda a gama ascendente e descendente - A letra $a$ atopábase escrita sobre o encerado e sobre as lousas dos nenos; 'avanzando!, avanzando!' Dicía el deseguida: 'eеeeeee E eeeeeee'; a mesma repetición e a mesma letra escrita no encerado e nas lousas ou pizarras dos nenos, e el continuou abordando as demais vogais. Cando escoitaba un son inadecuado, facíalle repetir a nota ao neno que fallara e o neno cantábaa só con el: así era como daba a lección e como revisaba as súas faltas. Logo volveu sobre a letra $a$, escribiuna dúas veces $(a a)$ e fixo solfexar estas dúas letras xuntas; deseguido colocou un $k$ diante das letras aa (kaa); e os nenos pronunciaron kaa; mentres que el os acompañaba de novo co violín, os nenos percorrían a gama ascendente e descendente. 'Sabedes vós, díxolles que é Kaa? Kaa é o nome dunha fermosa rapaza que viña a esta escola (diminutivo familiar de Catarina en holandés); era unha nena modelo e facía a felicidade dos seus pais.- Kaa foi responsable e fixo grandes progresos, e aínda non tiña dez anos cando os seus pais lle encontraron un traballo nun comercio, onde ela gaña o seu xornal. Hoxe Kaa sostén aos seus pais ben maiores. Vós queredes ser como Kaa?' E todos erguendo as súas mans dixeron que si. Deste xeito o sabio profesor Rijkens comeza a educación destes nenos pequenos.

Pasemos á segunda clase, composta por nenos saídos da primeira, con coñecementos de sons simples, de vogais e de sílabas.- Aquí continuamos o ensino primario da lectura, da escritura e da música; os exercicios son máis complexos, aínda que moi simples; o profesor indicounos nun dos seus excelentes manuais. Aquí só hai nenos; en horas distintas recórrense todas as materias do ensino primario. As dúas outras clases son só de nenas e estas catro divisións (ou seccións) están todas baixo a dirección de Rijkens, asistido por dous mestres- auxiliares.

A ximnástica é unha das ensinanzas desta escola: desde a máis tenra infancia os alumnos exercítanse en marchar, correr, saltar, etc.; todos estes exercicios son 
graduados e sucesivos, para poder desenvolver as súas forzas e rectificar, dado o caso, os defectos de sostemento ou de conformación. Corríxense tamén os defectos de costas.

O profesor Rijkens participa en todos estes exercicios; mestúrase nos xogos dos nenos e nas súas diversións. Aínda que, no medio desta ledicia e algareo, nunca perde de vista a finalidade que se propón: atrae e domina todas estas novas intelixencias, dálles a dirección que quere e conduce, avanzando, a educación física, moral e intelectual desta interesante infancia. El publicou para as escolas primarias un grande número de libros que eu vin que se usaban nas escolas de Groninga e de Frisia; escribiu numerosos e excelentes artigos nun periódico de educación (Tijdschrift voor onderwijzers, Groninga, 1837 e 1838); ademais, o seu libro sobre o debuxo lineal obtén un feliz éxito.

Educar e formar a infancia por medio de xogos e e cantos é a base do seu sistema: pensa con razón que os xogos son convenientes e propios para o carácter dos nenos; que o canto alixeira e suaviza todo xénero de exercicios. Un sistema análogo, tamén baseado sobre o canto, rexe hoxe en todas as escolas de Holanda" (1839, I, 92-95). 